\title{
Landscape Evolution of a Fluvial Sediment-Rich Avicennia marina Mangrove Forest: Insights from Seasonal and Inter-annual Surface-Elevation Dynamics
}

\author{
A. Swales,${ }^{1 *}$ G. Reeve, ${ }^{1}$ D. R. Cahoon, ${ }^{2}$ and C. E. Lovelock ${ }^{3}$
}

\begin{abstract}
${ }^{1}$ National Institute of Water and Atmospheric Research, NIWA, P.O. Box 11-115, Hamilton 3251, New Zealand; ${ }^{2}$ US Geological Survey, Patuxent Wildlife Research Center, Beltsville, Maryland 20705, USA; ${ }^{3}$ The School of Biological Sciences, The University of Queensland, St Lucia, Queensland, Australia
\end{abstract}

\begin{abstract}
Mangrove forests are vulnerable to accelerated sealevel rise associated with climate warming because they occupy a relatively narrow zone on the mid-toupper-intertidal flats. The fate of these ecosystems largely depends on their capacity to accrete sediment at a rate sufficient to maintain their elevation relative to sea level. We investigated the role of biophysical processes and feedbacks controlling surface-elevation dynamics in a fluvial sediment-rich Avicennia marina mangrove forest (New Zealand) at seasonal-to-interannual timescales (over 9 years) using the Rod Surface Elevation Table method. We found that sediment accretion in the forest was not measurably enhanced by episodic and short-lived storm discharges from rivers nor by elevated sea levels during storms. Critically, the coupling of frequent onshore winds and resulting resuspension of intertidal muds, with the
\end{abstract}

fortnightly cycle of spring tide inundation, controlled sediment delivery and resulting accretion rates of 13 to $47 \mathrm{~mm} \mathrm{y}^{-1}$. In turn, net surface-elevation trends of 0 to $28 \mathrm{~mm} \mathrm{y}^{-1}$ were dominated by the physical processes of sediment accretion and shallow subsidence due to seasonal desiccation and resulting compaction of the infrequently inundated forest platform (4 to $16 \mathrm{~mm} \mathrm{y}^{-1}$ ). Our data suggest that monthly and seasonal variation in tidally controlled hydroperiod and sediment delivery rather than episodic storm events are important for the maintenance of mangrove elevation within the intertidal zone.

Key words: hydroperiod; sediment accretion; subsidence; surface-elevation change; climate; sea level.
Received 11 February 2018; accepted 27 November 2018; published online 2 January 2019

Electronic supplementary material: The online version of this article (https://doi.org/10.1007/s10021-018-0330-5) contains supplementary material, which is available to authorized users.

Author Contributions AS conceived of and designed study; performed research, analysed data, contributed new methods, wrote the paper; GR analysed data and wrote the paper; DC designed study and wrote the paper; CL analysed data and wrote the paper.

*Corresponding author; e-mail: Andrew.Swales@niwa.co.nz

\section{HighLIGHTS}

- Surface-elevation dynamics of rarely studied sediment-rich mangroves are presented.

- Coupling of mud resuspension by waves with spring tides controls sedimentation. 
- Surface elevations are controlled by sedimentation and seasonal compaction.

\section{INTRODUCTION}

Global changes in marine environments associated with climate warming are already adversely influencing the capacity of ecosystems to maintain themselves and to provide services valued by society (Gattuso and others 2015). Coastal wetland ecosystems are particularly vulnerable to accelerated sea-level rise (SLR) as they occupy a relatively narrow elevation zone on the mid-to-upper-intertidal flats (Bird 1986; Clarke and Myerscough 1993; Baker and others 2015). In many estuarine and coastal settings, the potential for mangrove forests to adapt to rising sea levels by landward migration (Egler 1952; Cahoon and others 2009) is constrained by human infrastructure (for example, levee, embankments), resulting in coastal squeeze (Woodroffe and others 2016). Under these conditions, the degree of vulnerability of mangrove forest ecosystems to SLR largely depends on their capacity to accrete sediments at a sufficient rate to maintain their elevation relative to sea level (Friess and others 2012; Woodroffe and others 2016). Understanding of biophysical processes controlling surface-elevation dynamics in coastal wetlands, including mangrove forests, is key to devising management strategies for their survival (Webb and others 2013).

The relative contribution of the various processes controlling substrate surface elevations in mangrove forests vary with local environmental conditions. Surface processes include deposition and erosion of mineral sediments (primarily supplied by rivers), sediment desiccation, and seasonal variations in leaf litter and microbial mat production (Woodroffe 1985; McKee 2011; Webb and others 2013; Gladstone-Gallagher and others 2014; Swales and others 2015). Subsurface processes include regional tectonic processes that influence vertical land motion (VLM) (Kaye and Barghoorn 1964; Cahoon and others 1995; Cahoon 2015; Swales and others 2016; Woodroffe and others 2016), shallow and deep subsidence associated with sediment compaction by dewatering, as well as fluctuations in groundwater storage associated with evapotranspiration, seasonal rainfall and tidal cycle recharge and discharge (Cahoon and others 2011; Rogers and others 2014). In highly organic soils, root growth and decay and net organic matter accumulation can also influence shallow subsi- dence or expansion (McKee 2011; Krauss and others 2014).

Many of the insights regarding the role of biophysical processes and feedbacks controlling surface-elevation dynamics in coastal wetlands have come from studies employing the Surface Elevation Table and Marker Horizon (SET-MH) method (Boumans and Day 1993; Cahoon and others 1995; Webb and others 2013; Krauss and others 2014). The SET-MH and improved Rod Surface Elevation Table (RSET, Cahoon and others 2002) techniques have been applied in studies of mangrove forests dominated by peat sediment and mineral sediment deposition in tropical and temperate mangrove forest systems, including in Australasia (Rogers and others 2005a, b, 2006; Rogers and Saintilan 2008; Stokes and others 2009; Rogers and others 2013, 2014; Lovelock and others 2011, 2015a), Pacific Islands (Krauss and others 2003, 2010), Southern Asia (Kumara and others 2010; Sidik and others 2016), Central America (Cahoon and others 2003), Caribbean (McKee and others 2007; McKee 2011) and the Gulf Coast of North America (Cahoon and Lynch 1997; Whelan and others 2005).

With few exceptions (for example, Lovelock and others 2015b), many of these previous studies of surface-elevation dynamics in mangrove forests have focused on relatively fluvial sediment-poor systems (Whelan and others 2005; Rogers and others 2005a, 2006, 2013; McKee and others 2007; McKee 2011; Krauss and others 2003, 2008, 2014; Lovelock and others 2015a). Rates of surface-elevation gain in these fluvial sediment-poor systems are of a similar order to historical rates of sea-level rise (that is, several millimeters per year).

By contrast, few studies have considered the surface-elevation dynamics of rapidly accreting river deltas and muddy coasts (for example, $\mathrm{cm} \mathrm{y}^{-}$ ${ }^{1}$, Sidik and others 2016). These findings are at odds with the fact that the largest remaining mangrove forests globally are found in the relatively fluvial sediment-rich settings in the Indo-Pacific Region. The relative importance of sediment transport and delivery processes on surface-elevation dynamics in sediment-rich mangrove forests has also not been widely reported. Over seasonal-to-annual timescales, sediment accretion and surface-elevation gains in mangrove forests have also been linked to water turbidity (Lovelock and others 2015a). Key processes include wave resuspension, tidal asymmetry, flocculation, settling lag (for example, Postma 1961; Green and Coco 2007, 2014) and drag-induced dampening of flows by the aerial roots, trunks and canopies of mangrove trees (Woodroffe 1992; Young and Harvey 1996; Fur- 
ukawa and others 1997; Krauss and others 2003; Mazda and Wolanski 2009; Anthony and Gratiot 2012). Delivery of fluvial/mineral sediments to coastal wetlands in the upper-intertidal zone ultimately depends on hydroperiod (that is, frequency and duration of inundation, Reed 1990), which influences sediment accretion, soil fertility and plant growth (Cahoon and Reed 1995; Krauss and others 2006; Feller and others 2010).

Over geological timescales, coastal wetland evolution may follow a range of trajectories depending on sea level trends, tidal range, sediment supply and composition and local tectonic adjustments (for example, Allen 1990, 2000). As these systems mature, surface elevations asymptotically approach the upper limit of the tidal frame and meteorological and oceanographic processes may become increasingly important drivers of hydroperiod and resulting sediment delivery. Simple numerical mass balance process models have been used to explore the sensitivity of coastal wetland evolution to interactions and combinations of environmental drivers (for example, French 2006; Marani and others 2010; Fagherazzi and others 2012). Tidal inundation patterns in mature coastal wetlands are largely controlled by local surface elevation relative to the tidal frame and short- and long-term drivers of sea-level variability. In particular, storm surges and climate variability (for example, ENSO cycles) can episodically elevate sea level and modulate wave climate in estuaries over a range of timescales (Pugh 1987; Goring and Bell 1999; French 2006). Storm surges resulting in a temporary rise in sea level at the coast are primarily generated by shear stress associated with strong onshore winds and a small contribution due to low atmospheric pressure (that is, inverted barometer [IB] effect, Whunch and Stammers 1997; Kamphuis 2002). Storm surges measured on the New Zealand coast of up to one meter are relatively small in comparison with storm surges observed globally, where surges can exceed several meters (for example, Kamphuis 2002; Li and others 2006; Gong and others 2007). This is largely because extreme storm events in New Zealand are less energetic than in the tropics, Gulf of Mexico and the North Sea (for example), and the extratropical storm systems that episodically occur are fast moving (Goring 1995; Bell and others 2000). In our study, storm surge estimates derived from tide gauge records include the effects of wind stress.

The objective of our study is to determine the relative influence of surface and subsurface biophysical processes on seasonal-to-inter-annual surface-elevation dynamics in a fluvial sediment- rich Avicennia marina mangrove forest in New Zealand. The specific hypotheses tested in our study are: (1) local hydroperiod, as a proxy for sediment delivery, is a key predictor of sediment accretion and surface-elevation gain; (2) meteorological drivers such as episodic flood discharges from rivers and storm tides are important mechanisms enhancing sediment delivery to mangrove forests in the upper-intertidal zone; (3) distance from potential/most proximal sediment source (that is, unvegetated mudflats where sediment resuspension by waves occurs) is an important secondary factor controlling sediment accretion patterns; (4) mineral sediment accretion and compaction rather than biotic processes are the key factors controlling surface-elevation dynamics in fluvial sediment-rich systems.

\section{Study Area}

The Firth of Thames is an approximately $800 \mathrm{~km}^{2}$ mesotidal estuarine embayment located on the north-east coast of New Zealand's North Island $\left(37.25^{\circ} \mathrm{S}, 175.4^{\circ} \mathrm{E}\right)$ (Swales and others 2015). Tides in the Firth are semi-diurnal with average springand neap-tidal ranges of 2.8 and $2 \mathrm{~m}$, respectively (Swales and others 2007). The Firth is one of numerous estuaries fringing the east coast of the upper North Island that have experienced substantial increases in mangrove forest (Avicenna marina) habitat in recent decades. Here, mangrove forest has colonized rapidly accreting mudflats $\left(\mathrm{cm} \mathrm{y}^{-1}\right)$ since the early 1960s (Swales and others 2015) (Figure 1) and is part of a pattern of seaward expansion of mangrove forests on intertidal flats observed in many North Island estuaries. Rates of expansion have averaged $4 \% \mathrm{y}^{-1}$ since the $1930 \mathrm{~s}$ (Morrisey and others 2010). The growth of these fringing vegetated habitats has followed large-scale catchment deforestation and resulting in increased soil erosion and estuary sedimentation since the mid-1800s (for example, Hume and McGlone 1986; Sheffield and others 1995; Swales and others 2002; Oldman and others 2009; Gibbs and others 2014). Detailed descriptions of the geology and recent history of the study area are presented in Swales and others $(2015,2016)$.

Fluvial sediments are supplied to the southern Firth by the Waihou and Piako rivers, which discharge an estimated $190,000 \mathrm{t} \mathrm{y}^{-1}$ of suspended sediments (Hicks and others 2011) from a $3,440 \mathrm{~km}^{2}$ watershed. Fetch- and depth-limited estuarine waves, driven by onshore northerly winds, rework the mudflat and drive an onshore flux of suspended muds. Near-bed concentrations 


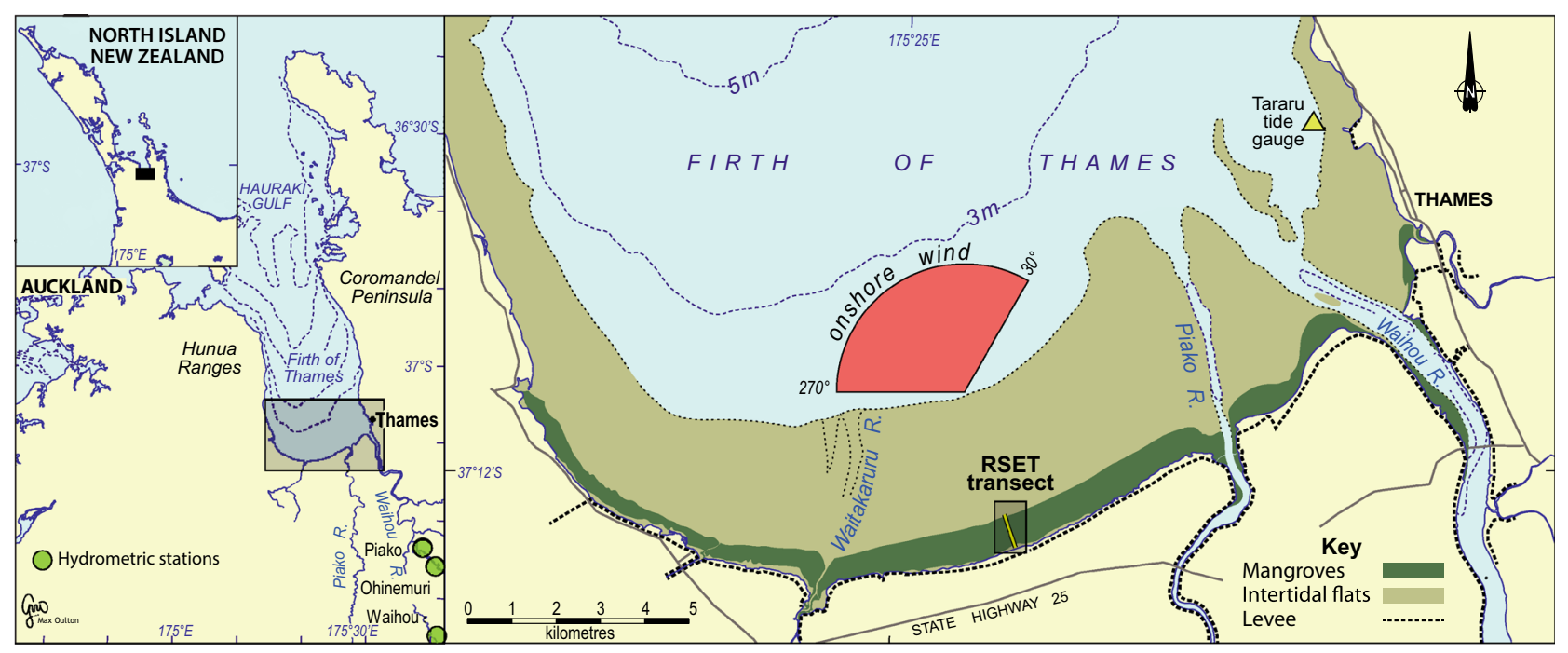

Figure 1. Map of the study area, southern Firth of Thames, New Zealand. Locations of the Rod Surface Elevation Table (RSET) benchmark transect, Tararu tide gauge, climate and hydrometric stations (inset map) shown. The window for onshore winds $\left(270-30^{\circ} \mathrm{T}\right)$ used as a proxy for sediment remobilization and onshore transport by waves is represented by the arc.

of suspended muds regularly exceed $\mathrm{l} \mathrm{g} \mathrm{l}^{-1}$ inside the mangrove forest fringe along our study transect, under these onshore sea breezes (Balke and others 2015). A substantial fraction of this mud has rapidly accumulated in the mangrove forest (that is, ${ }^{210} \mathrm{~Pb}$ sediment accumulation rates [SAR] $\sim 10$ $60 \mathrm{~mm} \mathrm{y}^{-1}$, Swales and others 2015). Over the last several decades, these smectite clay-rich sediments (Naish and others 1993) have built a kilometerwide vegetated tidal flat platform with surface elevations that are now above mean high-water spring (MHWS) tide (Swales and others 2015). GPS surveys of RSET benchmarks and sedimentary records indicate that sedimentation on the mangrove forest platform is enhanced by creation of accommodation space (that is, volume) through subsidence (that is, $\sim 7-9 \mathrm{~mm} \mathrm{y}^{-1}$ ). This phenomenon occurs primarily due to deep compaction of unconsolidated deposits in a sedimentary basin, so that relative sea-level rise (RSLR) is about $10 \mathrm{~mm} \mathrm{y}^{-1}$ on this coast (Swales and others 2016).

Mangroves colonized the rapidly accreting intertidal flat from the early-1960s once the substrate surface had reached mid-intertidal elevation and progressively established on seaward-prograding mudflats (Swales and others 2015). Major mangrove recruitment events occurred episodically, on average at decadal intervals, during rare disturbance-free periods (Balke and others 2015). These events appear to have coincided with times of calm weather (Lovelock and others 2010) and transition from spring-to-neap tides, when stran- ded propagules had sufficient time to firmly anchor in the substrate, thereby resisting subsequent bed erosion by waves under onshore winds. Periods of onshore winds $\left(270^{\circ}-30^{\circ}\right.$ True $)$ and calm occur $35 \%$ and $6 \%$ of the time, respectively (NIWA climate station: C75241, 2010-2016).

\section{MethodS}

\section{Research Design}

Surface-elevation changes, sediment accretion rates and hydroperiod were measured at replicate RSET stations $(N=3)$, which were randomly located along a shore-normal transect (Figure 2) in each of three major forest zones identified by Swales and others (2015) and based on the classification of Lugo and Snedaker (1974). These forest zones represent a temporal sequence of tidal flat colonization by mangrove including: (1) relict fringe forest (trees that were tall seaward fringing trees in the 1970s); (2) scrub forest composed of shorter trees formed within a comparatively hydrologically isolated area (mid-1990s-present); and (3) tall seaward-mudflat fringing trees of the fringe forest (early-1990s) (Lovelock and others 2010). These forest zones occupy a range of elevations within the tidal frame and distances from the unvegetated mudflat (Figure 2) over which vegetation and sediment parameters vary, with total sediment nitrogen and carbon contents (varying from 2 to $6 \%$ for nitrogen and 8 to $14 \%$ for carbon) and soil Redox potential (varying from 


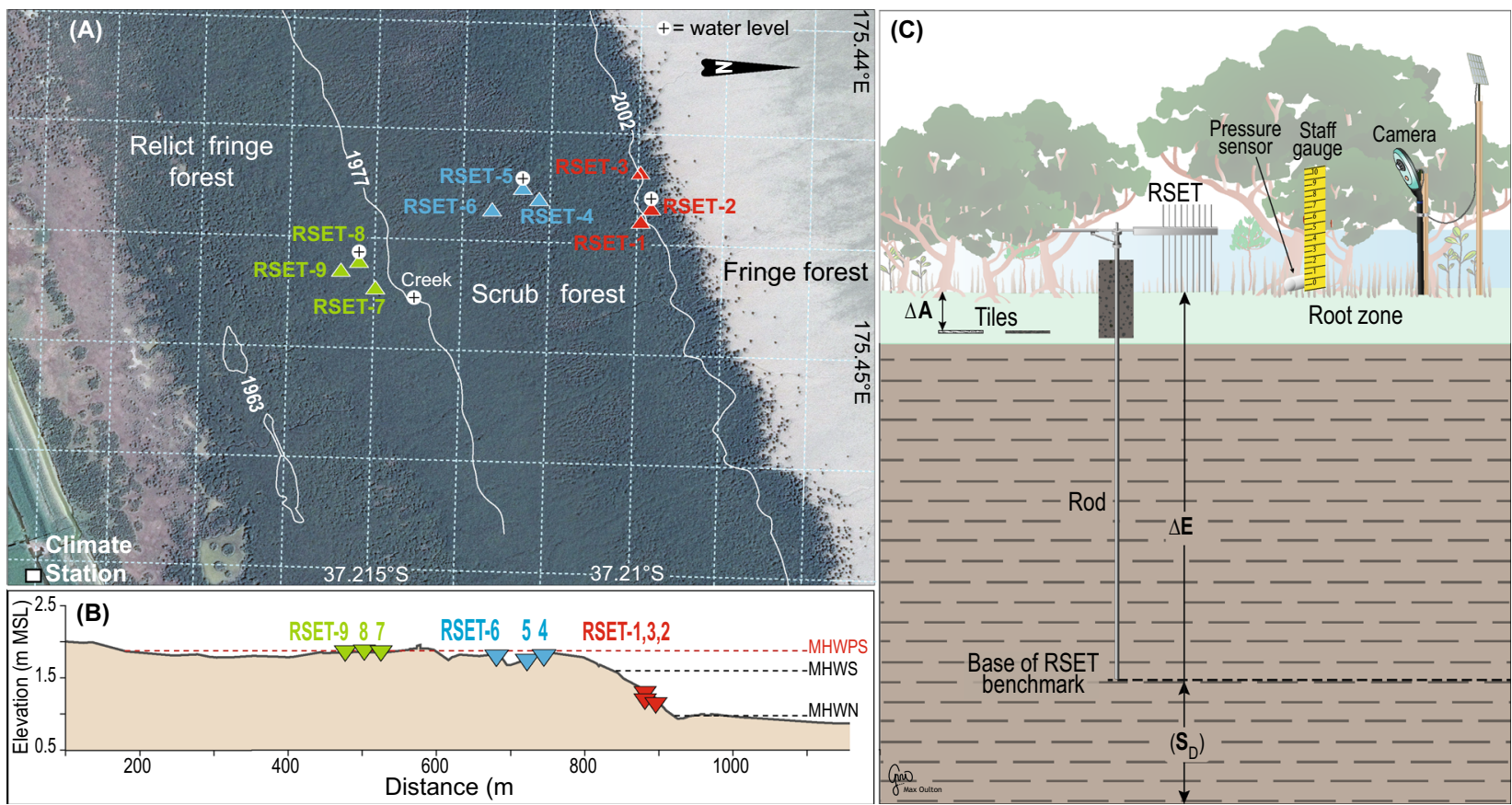

Figure 2. Location map of: A Rod Surface Elevation Table (RSET) benchmarks, climate station and water-level recorders; B cross-shore transect showing the elevations of the RSET relative to mean sea level. Mean high water neap (MHWN), spring (MHWS) and perigean spring (MHWPS, moon at closest approach to earth) tide levels are also indicated; and C schematic of sediment accretion $(\Delta A)$, surface-elevation change $(\Delta E)$ and hydroperiod measurements made at RSET stations. Deep subsidence $\left(S_{\mathrm{D}}\right)$ and $\Delta E$ are measured relative to the base of the stainless steel RSET benchmark.

- 150 to $100 \mathrm{mV}$ ) increasing from the seaward to the landward edge of the mangrove (Lovelock and others 2010).

Hydroperiod was measured using pressure sensors and cameras (1 January 2011 to 29 January 2014) deployed at an RSET station located in each forest zone: present fringe (RSET-2), scrub forest (RSET-5) and relict fringe forest (RSET-8) and a tidal creek that flows through the relict fringe forest (Figure 2C). Meteorological variables recorded at 10-minute intervals (NIWA climate station: C75241, Figure 2) include mean air pressure and temperature, rainfall and wind speed and direction. As described below, the mean speed of the onshore wind component $\left(270^{\circ}-30^{\circ}\right.$ True $)$ was used as a proxy for sediment supplied to the forest by wave resuspension on the intertidal mudflats. Instantaneous river discharge for the Waihou and Piako rivers (Figure 1) provided a proxy for fluvial sediment supply. These environmental data along with the rates of sediment accretion $(\Delta A)$, surface-elevation change $(\Delta E)$ and inferred shallow subsidence $\left(S_{\mathrm{S}}\right)$ were used in an analysis of factors controlling $\Delta A$ and $\Delta E$, as described below. $\Delta A, \Delta E$ (that is, $\mathrm{mm} \mathrm{y}^{-1}$ ) and associated potential predictors were calculated for the eight sampling intervals (Figure 3) (Supplementary Information) coinci- dent with the three-year record of hydroperiod data.

\section{Surface-Elevation Changes}

Surface-elevation changes in the mangrove forest were measured over a nine-year period (March 2007-April 2016) using the RSET method (Cahoon and others 2002), with benchmarks installed in February 2007. The installation of the 18-m-deep benchmarks is described by Swales and others (2016), with each benchmark consisting of 12 sections of $1.5-\mathrm{m}$-long threaded stainless steel rod driven vertically into the substrate. Measurements $(n=18)$ were taken at 4 - to 12 -month intervals, with the approximately four-monthly surveys coinciding with the hydroperiod measurements (2011-2014). Substrate surface elevations were determined relative to each RSET benchmark as a mean value calculated from 36 point measurements spread over four directions, offset at ninety degrees. These data were used to determine rates of substrate surface-elevation change over seasonalto-annual timescales. 


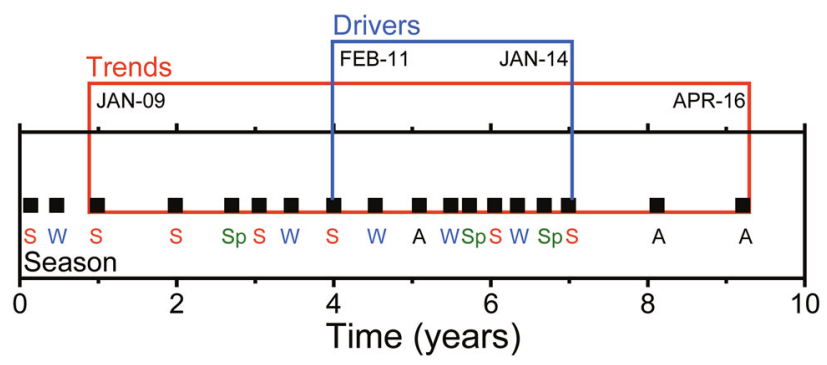

Figure 3. Summary of data time series used in the study. The timing of Rod Surface Elevation Table (RSET) measurements during the 9.2-year sampling period (March 2007-April 2016) is indicated by the closed, black squares. Time (years) is relative to the installation of the RSET benchmarks in February 2007. The season of the RSET measurements is indicated as summer [S], autumn (A), winter [W], and spring [Sp]. The time period of measurement of sediment accretion and surface-elevation trends (January 2009-April 2016) is indicated by the red box (Trends). The three-year data time series used to identify environmental drivers of the accretion and elevation trends (February 2011-January 2014), using boosted regression tree analysis and generalized additive models, is indicated by the blue box (Drivers) (Color figure online).

\section{Sediment Accretion}

Sediment accretion rates $\left(\mathrm{mm} \mathrm{y}^{-1}\right)$ at each RSET station were determined using several methods in addition to the standard feldspar marker horizon method (Cahoon and Turner 1989). Of the methods evaluated, we used accretion on ceramic and mesh plates buried by progressive sedimentation (Supplementary Information).

The thickness of sediment deposited on the ceramic and plastic-mesh plates was measured using 4-mm-diameter rigid plastic straws. Five measurements were made on each plate, randomly along cardinal directions and approximate centre, and at least $2 \mathrm{~cm}$ from the edges. Apparent bias in sediment accretion rates estimated from the ceramic plates initially occurred until self-burial to several centimeters depth had occurred (Supplementary Information Figure S1). To account for this measurement artefact, elevation and accretion data from the first three sampling events were omitted from the estimation of shallow subsidence $\left(S_{\mathrm{S}}\right)$.

\section{Shallow Subsidence}

Rates of shallow subsidence $\left(S_{\mathrm{S}}\right)$ due to compaction and other subsurface processes in the mangrove forest sediments were inferred from the sediment accretion $(\Delta A)$ and surface-elevation trends $(\Delta E)$ measured at each RSET station (that is, $S_{\mathrm{S}}=\Delta A-$ $\Delta E)$. Shallow subsidence is indicated when $\Delta E<$ $\Delta A$ (Cahoon and others 1995).

\section{Root Biomass Production}

Root biomass production was measured at each RSET station using ingrowth bags (Lund and others 1970; McKee and others 2007; Lovelock and others 2015a) to evaluate the potential contribution of root growth to substrate surface elevation over a single 12-month period (March 2012 to March 2013). Five root ingrowth bags were randomly located within an approximate $10 \mathrm{~m}$ radius of each RSET benchmark. The bags were made using $5-\mathrm{cm}$ diameter and 20-cm-long tubes of nylon mesh (2$\mathrm{mm}$ weave) filled with root-free surficial muds collected in the vicinity of each RSET station. The sealed ingrowth bags were inserted vertically into similar-sized holes excavated into the substrate. At the end of the 12-month period, the ingrowth bags were processed to estimate root production as dry mass $\left(\mathrm{g} \mathrm{m}^{-2} \mathrm{y}^{-1}\right)$ and volume $\left(\mathrm{m}^{3} \mathrm{~m}^{-2} \mathrm{y}^{-1}\right)$ (Supplementary Information).

\section{Sediment Properties}

The bulk properties of sediments deposited at each RSET station over a six-year period following installation (February 2007-June 2013) were determined from sediment cores collected in 30$\mathrm{cm}$-long $\times 5$-cm-diameter Perspex tubes. Parameters calculated were: dry bulk sediment density; sediment porosity; and organic matter content (Supplementary Information).

\section{Hydroperiod}

The duration and frequency of tidal inundation (that is, hydroperiod) was measured at an RSET station in each forest zone and the tidal creek site (Figure 2) using two independent methods: (1) water depth inferred from pressure sensors deployed at the bed; and (2) direct measurements of water depth using time-lapse images of hydrometric staff gauges. Because water depths on the upper-intertidal mangrove forest platform were anticipated to be less than $0.5 \mathrm{~m}$, the time-lapse 
images were used to calibrate water depths inferred from the pressure sensor data (Supplementary Information).

Water depth was estimated from absolute pressure data recorded at each station using Onset Computer Corporation HOBO ${ }^{\circledR}$ model U20-001-04 titanium pressure sensors (range: $0-4 \mathrm{~m}$ ). Pressure sensors were deployed for five years (December 2010-December 2015). Total pressure and temperature $\left({ }^{\circ} \mathrm{C}\right)$ were measured at ten-minute intervals, with sensors synchronized to the nearest second (New Zealand Standard Time, NZST). Data from the climate station were used to remove the atmospheric pressure component, thereby estimating water depth $(h)$ using the simplified hydrostatic pressure equation from $p=\rho g h$, where $p$ is the hydrostatic pressure $\left(\mathrm{Pa}, \mathrm{kg} \mathrm{m}^{-1} \mathrm{~s}^{-2}\right), \rho$ is the fluid density $\left(\mathrm{kg} \mathrm{m}^{-3}\right)$ and $\mathrm{g}$ is gravitational acceleration $\left(9.81 \mathrm{~m} \mathrm{~s}^{-2}\right.$ ) (Munson and others 1998, Supplementary Information). Hydroperiods (\% total time) for each RSET station were calculated for the three-year period of seasonal elevation measurements (that is, February 2011-January 2014) and subsequent statistical analysis of environmental factors controlling sediment accretion and surface-elevation change. Details of the pressure sensor and time-lapse image analysis are described in the Supplementary Information.

\section{Wind Climate and River Discharge}

Wind climate and river discharge data coincident with the three-year hydroperiod record were used, respectively, as proxies for sediment supply by wave resuspension of intertidal muds and fluvial fine-sediment inputs. The use of these proxies is supported by knowledge of sediment transport in these systems. Firstly, wave-driven "turbid fringes" (Green and others 1997) of resuspended muds are a characteristic feature of sediment transport on intertidal flats under windy conditions in New Zealand's mesotidal, fetch-limited estuaries. On down-wind shores, suspended sediment concentrations (SSC) are highest in the turbid fringe, located near the leading edge of the flood tide (Green and Coco 2014, and references therein). The turbid fringe is also a feature of our study site. Earlier, Balke and others (2015) analysed a 9-month time series of wind climate to assess the relationship between wind and SSC data inferred from an optical backscatter record from the mangrove fringe forest near RSET2 (Figure 2). They found that frequent resuspension of intertidal muds by waves and flood tide advection into the mangrove forest occurred under onshore wind conditions. With regards to fluvial sediment inputs, high river discharges transport the majority of long-term catchment-suspended sediment loads and event loads are positively and well correlated with peak storm discharges (for example, Gray and Simões 2008; Hicks and Gomez 2016). These observations suggest that the use of wind climate and river discharge as proxies for sediment supply over seasonal-to-inter-annual timescales is reasonable. Mean wind speed and direction data measured 10$\mathrm{m}$ above ground level at 10-minute intervals was classified into onshore $\left(270^{\circ}-30^{\circ}\right.$ True $)$ and offshore components. The onshore component identified time periods during which wave propagation would potentially resuspend mudflat sediments and generate an onshore sediment flux (Balke and others 2015). Instantaneous river discharge $\left(\mathrm{m}^{3} \mathrm{~s}^{-}\right.$ ${ }^{1}$ ) was recorded at hourly intervals at hydrometric stations on the Ohinemuri, Waihou and Piako rivers (Figure 1). Summary statistics were calculated for the time periods between RSET readings.

\section{Storm Surge}

The storm surge component of the Tararu sea-level record during the three-year period of interest was estimated from tidal-harmonic analysis of hourly sea-level data to derive predicted tides using the MATLAB ${ }^{\circledR}$ application T_TIDE (Pawlowicz and others 2002). The variance in the observed tide explained by the harmonic analysis was $92 \%$. The remaining unexplained variance includes storm surge events, longer-term sea-level variability associated with climate (for example, El Niño Southern Oscillation, Interdecadal Pacific Oscillation, Bell and others 2000) and prediction errors in the harmonic analysis. The storm surge component (m) of the observed sea level, due to wind stress and the IB effect, was calculated from the non-tidal residual time series (that is, observed - predicted sea level). This was achieved by wavelet filtering of the non-tidal residual to extract the main meteorologically forced components by removing highfrequency prediction errors (that is, $<24 \mathrm{~h}$ ) and seasonal effects (that is, $>1$ month) (Goring and others 2011).

Wavelet-filtering of the non-tidal residual was used to calculate storm surge in preference to the skew surge method (de Vries and others 1995; Williams and others 2016) because storm surge duration and resulting hydroperiod controls sediment delivery to the mangrove forest (Swales and others 2015). Surge duration was defined as the length of time that the estimated surge equalled or exceeded a $0.3 \mathrm{~m}$ threshold. Storm surges in the 
Firth of Thames are typically of moderate size, with median values for the five largest storm surges in any given month in the range of 0.3 to $0.4 \mathrm{~m}$ (1990-2014). Storm surges of $0.3 \mathrm{~m}$ have an average recurrence interval of about one year (Stephens and others 2015). Such moderate-sized surges dominate storm tides around the New Zealand coast (Stephens and others 2014).

The wavelet-filtering method will produce the most accurate estimate of surge duration per event because it is designed to filter out tidal prediction errors and because the hourly time-step of the nontidal residuals provides a substantially higher temporal resolution than the approximately 12-hourly resolution of the skew surge estimate. Storm surge amplitude was incorporated into our analysis of sediment accretion and elevation change drivers to the extent that we identified storm surge events of at least $0.3 \mathrm{~m}$ and applied their associated event durations to that analysis. The cumulative duration of storm surge events of at least $0.3 \mathrm{~m}$ between RSET measurements were included in the analysis of sediment accretion and elevation drivers, as described below.

\section{Statistical Analysis}

Statistical analyses were performed using STATISTICA version 12 (Dell Software) and open-source code written in R (R-core@R-project.org). Linear regression analysis was used to determine rates of sediment accretion, substrate elevation gain and shallow subsidence rates $\left(\mathrm{mm} \mathrm{y}^{-1}, 2007-2016\right)$. A nested ANOVA ( $\alpha=0.05)$ was used to test for differences in mean root production (MRP, $\mathrm{g} \mathrm{m}^{-2} \mathrm{y}^{-}$ $\left.{ }^{1}\right)$ with the RSET stations (random factor) nested within Forest zone (fixed factor, fringe, scrub, relict fringe). The MRP data were transformed using a cube-root. This provided the largest improvement in the symmetry and variance of the sample distribution, which was negatively skewed (Supplementary Information). Three of the ingrowth bags contained no fresh root material, which is indicative of spatial variations in root biomass growth during the 12-month measurement period.

Factors driving sediment accretion $\left(\Delta A, \mathrm{~mm} \mathrm{y}^{-1}\right)$ and surface-elevation change $\left(\Delta E, \mathrm{~mm} \mathrm{y}^{-1}\right)$ at RSET stations over seasonal-to-inter-annual timescales during the three-year period of hydroperiod measurements (Figure 3) were explored using two methods: (1) linear and nonlinear mixed effects generalized additive models (GAM) fitted by maximum likelihood and (2) generalized boosted regression tree (BRT) analysis (De'ath 2007; Elith and others 2008). The BRT and GAM models were developed for the environmental conditions that occurred during the three-year period of hydroperiod measurements (Figure 3), and using other potential environmental drivers as described below. Both types of modelling were undertaken in R (Rcore@R-project.org). The GAM analysis employed the "nlme" code (Gaussian Linear and Nonlinear Mixed Effects Models) version 3.1-128 (José Pinheiro [aut] and others 2016). The BRT code "gbm.step" version 2.9 (Generalized Boosted Regression Models, Elith and others 2008), which builds on code developed by Ridgeway (2006), was used to facilitate data analysis and interpretation.

Boosted Regression Trees are one of a family of machine learning methods that have been less frequently used for prediction in ecological studies than statistical methods (Elith and others 2008), although this is changing (for example, Leathwick and others 2008; Martínez-Rincóna and others 2012; Lovelock and others 2015b; Steel and others 2017). In BRT models, the relationship between response variables and predictors is learnt using an algorithm to find the dominant patterns and makes no assumptions about the form of the model (Elith and others 2008). BRT models also have several advantages over GAM, which include no requirement for data transformations, insensitivity to outliers and different scales of measurement, automatic fitting of complex nonlinear interactions between predictors and identification of thresholds in response (Elith and others 2008; Leathwick and others 2008).

Generalized Additive Models have been commonly employed to address ecological questions and complement the BRT analysis to identify key drivers of sediment accretion and elevation change. In our study, GAM (maximum likelihood, ML) fit diagnostics computed by the "nlme" package included the Akaike information criterion (AIC) and the related Bayesian Information Criterion (BIC). Comparison of models using the AIC and BIC assumes that the log-likelihood has been maximized, with smaller values indicating better model fit (Rcore@R-project.org, Venables and Ripley 2002). As described below, the final GAMs were substantially improved by second-order polynomial transforms of the hydroperiod and mean air temperature drivers. This was consistent with BRT results (that is, partial dependency plots), which indicated a quadratic response of sediment accretion and elevation change to hydroperiod and mean air temperature.

Potential drivers (factors) considered in the GAM and BRT modelling for which data were available include: 
1. Forest zone - fringe, scrub and relict fringe forests (Fzone)

2. Distance from un-vegetated mudflat (MFdist, $\mathrm{m})$

3. Mean onshore wind speed $\left(270^{\circ}-30^{\circ}, W_{\text {mean }}\right.$ $\mathrm{m} \mathrm{s}^{-1}$ )

4. Sum of mean instantaneous river discharges $\left(\Sigma Q_{\text {mean }}, \mathrm{m}^{3} \mathrm{~s}^{-1}\right)$

5. Storm surge $\geq 0.3 \mathrm{~m} \quad\left(\mathrm{ST}_{\geq 0.3 \mathrm{~m}}\right.$, duration as $\%$ of time)

6. Hydroperiod (Hp \% of time)

7. Mean water depth while inundated $\left(h_{\text {mean }}, \mathrm{m}\right)$

8. Mean air temperature $\left(T_{\text {mean }},{ }^{\circ} \mathrm{C}\right)$

9. Total rainfall $\left(R_{\mathrm{tot}}, \mathrm{mm}\right)$

Exploratory data analyses, including correlations, were used to inform the modelling. Strong correlations between predictor variables may reduce the accuracy of measures of their importance, such as their significance, relative influence and functional information encapsulated in GAM and BRT models (that is, partial dependency plots) that provide insights into predictor-response relationships and associated environmental conditions (De'ath 2007; Elith and others 2008). Particularly strong correlations between Fzone and MFdist $(r \sim 0.9$, Supplementary Information) indicated that these potential drivers of sediment accretion and elevation change should be evaluated in separate models. Significant correlations were also identified for both Fzone and MFdist with hydroperiod and mean water depth, and between river discharge and mean air temperature.

The relatively strong correlations identified were explored to determine which, if any, of the predictor variables could be discarded or transformed to reduce the correlation. The mean river discharge predictor was subsequently discarded from the final GAM and BRT models (Supplementary Information).

To account for the correlations between mean water depth $\left(h_{\text {mean }}\right)$ and distance from the mudflat (MFdist) $(r=-0.76)$, residuals derived from a simple linear regression of MFdist with $h_{\text {mean }}$ (Estimate $=-1132, \mathrm{SE}=116.1$, adjusted $r^{2}=0.57$, $t=-9.747, p=1.15 \mathrm{e}^{-14}, \quad F=95$ on $1, d f=70$ ) were used in the model such that distance effects, independent of depth, could then be assessed using the residuals $\mathrm{Hz}_{\text {resid }}$ as a derived distance variable (Supplementary Information). The BRT models were implemented with learning rates $=0.005$ $(\Delta A)$ and $0.01(\Delta E)$, bag fraction $=0.5$ and tree complexity $=1$, based on detailed evaluation of model performance with simplification using the cross-validated deviance $(\mathrm{CV}-\mathrm{D}$, that is, predictive deviance) (Supplementary Information). The final models for $\Delta A$ and $\Delta E$ included four (that is, $\mathrm{Hp}$, $W_{\text {mean }}, T_{\text {mean }}, \mathrm{Hz}_{\text {resid }}$ ) and three predictors (that is, $\left.\mathrm{Hp}, T_{\text {mean }}, h_{\text {mean }}\right)$, respectively.

Functional dependencies between the $\Delta A$ and $\Delta E$ response variables and predictor variables in the final BRT models were represented in partial dependency plots (Friedman 2001). The relative influence (RI, \%) of each predictor in the final models represents the contribution of each predictor to the total reduction in the fitted model's predictive $(\mathrm{CV})$ deviance.

\section{RESUlts}

\section{Meteorological Conditions and Hydroperiod}

Inter-annual variability in mean annual onshore wind speed and its duration was negligible during the study period. Onshore winds occurred 33-34\% of the time, averaging $4.1-4.5 \mathrm{~m} \mathrm{~s}^{-1}$. Storm surge events with sea-level elevated by $0.3 \mathrm{~m}$ or more above predicted tides occurred $0.2-0.6 \%$ of the time per year. Combined mean annual river discharges of $65 \mathrm{~m}^{3} \mathrm{~s}^{-1}$ (that is, Waihou, Ohinemuri and Piako) also displayed negligible inter-annual variability. These annual statistics mask the contribution of episodic storms, which increase wind speeds, sea level and river discharges over timescales of hours to days (discussed below).

Annual total hydroperiods were consistently higher at the creek site (23 to $25 \%$ ) than in the fringe ( 14 to $24 \%)$, scrub $(4-9 \%)$ or relict fringe forests $(6$ to $8 \%$ ) over the three-year period. Mean annual water depths were also consistently higher and more variable (as indicated by standard deviations) in the fringe forest ( 0.28 to $0.34 \mathrm{~m}$ ) than in the scrub $(0.09$ to $0.11 \mathrm{~m})$ or relict fringe forest $(0.10$ to $0.11 \mathrm{~m})$ zones (Supplementary information).

Analysis of individual tidal inundation events show that inundation of the fringe forest was five to ten times more frequent (that is, $n=1,476,2011$ to 2014) than in the scrub and relict fringe forests respectively $(n=270$ to 171 ; Supplementary Information). Inundation events in the fringe forest, averaging 3.6 hours in duration, were associated with spring tides. Notably, mean hydroperiods in the scrub and relict fringe forests of $6-10$ hours were 2-3-fold longer than in the fringe forest.

Time series data illustrate how meteorological and tidal forcing influences tidal inundation of the mangrove forest over hourly to daily timescales, under a range of conditions. Figure 4 presents 

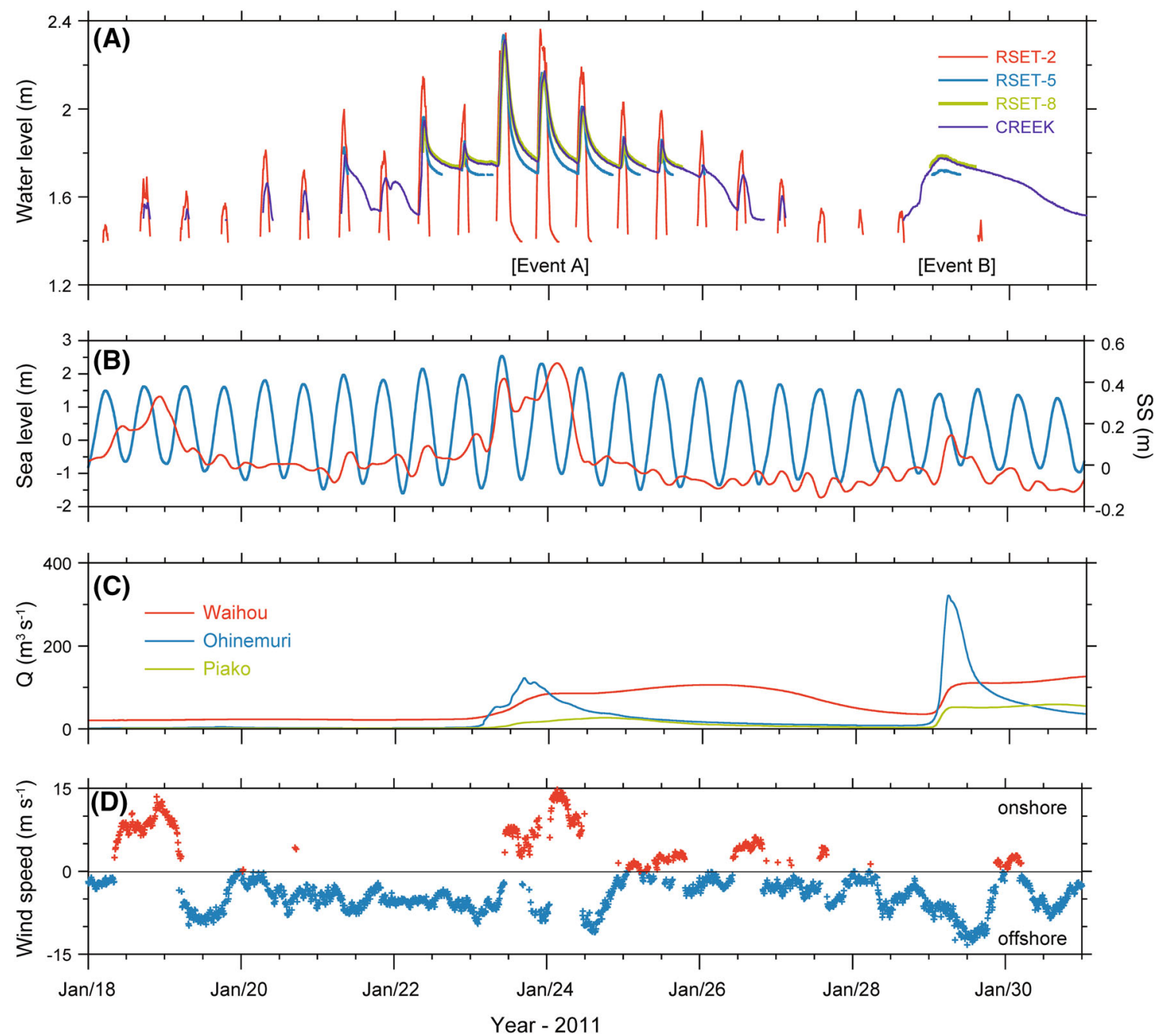

Figure 4. Events A \& B: meteorological, tidal and hydrological conditions, southern Firth of Thames (18-31 January 2011). Time series of: A water levels at primary RSET stations and creek (m, Moturiki Vertical datum 1953 [MVD-53]); B measured sea level (blue) at Tararu (m MVD-53) and calculated storm surge (SS, red) component; C instantaneous river discharge; and $\mathbf{D}$ onshore $\left(270-030^{\circ} \mathrm{T}\right.$, red symbols) and offshore (blue symbols) wind speeds. Data sources: B, C Waikato Regional Council and D NIWA Climate Station Firth of Thames EWS C75241 $\left(37.21522^{\circ}\right.$ S, $175.4503^{\circ}$ E, Figure 2$)$.

examples of event types: spring tide + storm surge $(\sim 0.5 \mathrm{~m})+$ onshore winds $\left(\leq 15 \mathrm{~m} \mathrm{~s}^{-1}\right)$ (Event A); and neap tide + high river discharge $(\Sigma Q$ $420 \mathrm{~m}^{3} \mathrm{~s}^{-1}$ ) (Event B).

Tidal inundation occurs more frequently in the fringe forest due to its lower elevation in the intertidal zone, but of shorter duration (that is, RSET- $2<4$ hours) than in the scrub and relict fringe forest where ponding is indicated by extended recession of hydrographs (Figure 4A). During spring tides, the entire mangrove forest is inundated. Water levels in the forest are enhanced when high spring tides coincide with episodic storm surge events generated by onshore winds and a small contribution due to low atmospheric pressure (for example, 24 Jan 2011 , Figure 4B, D
Event A). These data also show that large stormwater discharges from the Waihou, Ohinemuri and Piako Rivers also episodically inundate the mangrove forest (Figure 4C). The storm of 2930 January 2011 (Event B), which coincided with neap tides and offshore winds, generated a peakfreshwater discharge of $420 \mathrm{~m}^{3} \mathrm{~s}^{-1}$ to the southern Firth and resulted in ponding in the scrub and relict fringe forests (Figure $4 \mathrm{~A}$ and $\mathrm{C}$ ).

\section{Sediment Accretion and Surface- Elevation Trends}

Cumulative trends of surface-elevation changes measured over the entire 9.2-year record showed consistent and linear increases in elevation at all 
RSET stations (Figure 5 and Supplementary Information). Rates of surface-elevation gain, estimated using linear regression analysis, were highest in the fringe forest $\left(\sim 31\right.$ to $\left.35 \mathrm{~mm} \mathrm{y}^{-1}\right)$, close to the unvegetated mudflat, and lowest in the relict fringe forest $\left(\sim 8\right.$ to $\left.10 \mathrm{~mm} \mathrm{y}^{-1}\right)$ several hundred meters landward. In the scrub forest, rates of surface-elevation gain $\left(\sim 9\right.$ to $\left.20 \mathrm{~mm} \mathrm{y}^{-1}\right)$ show a progressive reduction with distance landward across the upperintertidal platform.

Figure 6 summarizes net rates of sediment accretion $\left(\Delta A, \mathrm{~mm} \mathrm{y}^{-1}\right)$ and surface-elevation change $\left(\Delta E, \mathrm{~mm} \mathrm{y}^{-1}\right)$, which occurred during the three-year (2011-2014) period of hydroperiod measurements. Net per-annum accretion rates of up to $90 \mathrm{~mm} \mathrm{y}^{-1}$ displayed substantial variability within each sampling period, with highest rates occurring in the fringe and scrub forest. Net erosion not exceeding $30 \mathrm{~mm} \mathrm{y}^{-1}$ occurred on several occasions in all three forest zones. Likewise, net surface-elevation changes displayed substantial variability among RSET sampling events and forest zones.

Elevation change for sampling intervals from 2011-2014 displayed a seasonal cycle (that is, winter/spring to summer) in the scrub and relict
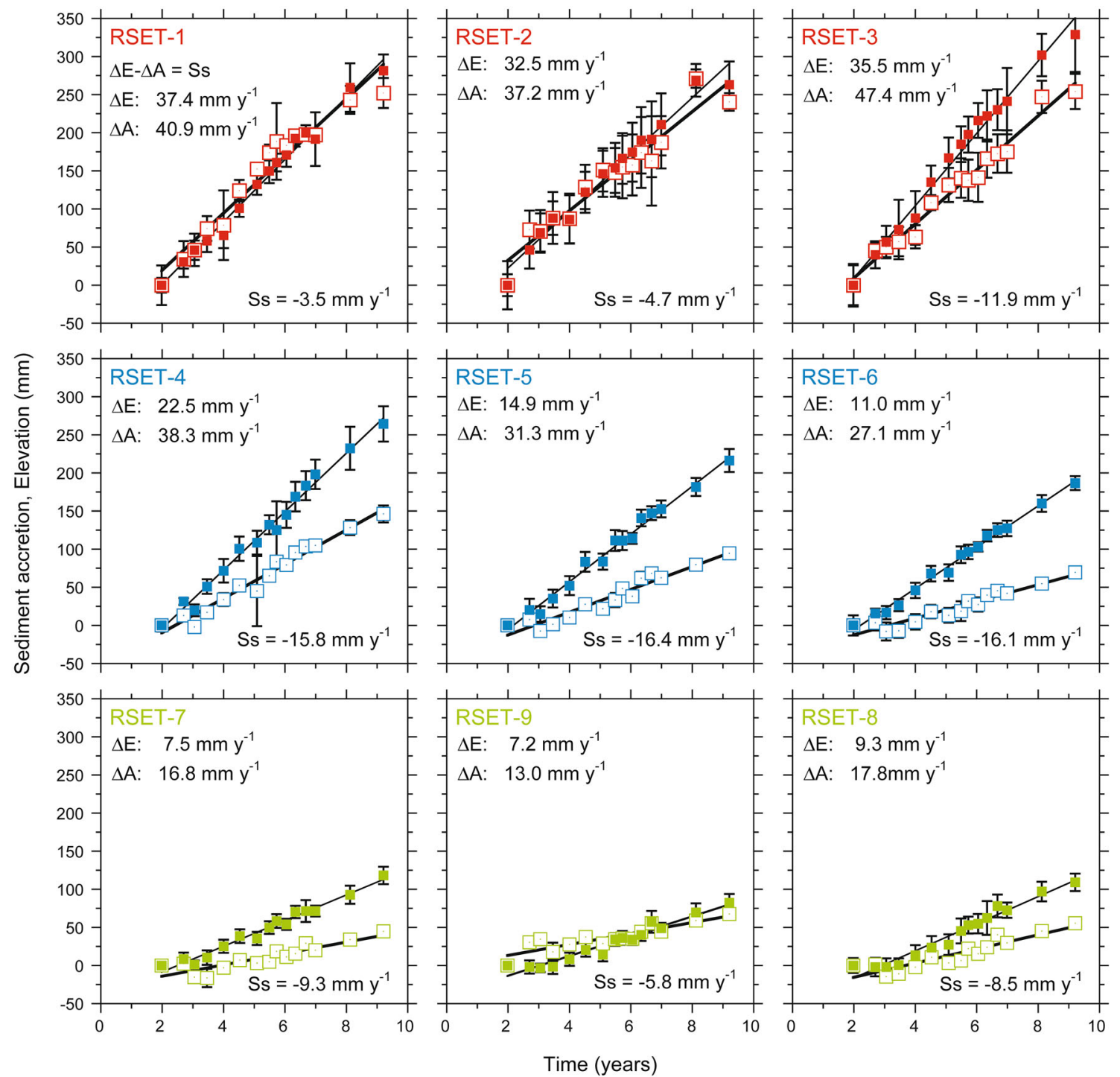

Figure 5. Cumulative elevation trends and shallow subsidence $\left(\mathrm{S}_{\mathrm{S}}, \mathrm{mm} \mathrm{y}^{-1}\right)$ inferred from surface-elevation $(\Delta E)$ and sediment accretion $(\Delta A)$ trends at RSET stations (27 January 2009-19 April 2016) determined from linear regression of mean surface elevations and sediment accretion $(40 \times 40 \mathrm{~cm}$ plates) measured at: fringe forest (RSET 1-3); scrub forest (RSET 4-6); and relict fringe forest (RSET 7-9) sites. $P \leq 0.00001(n=15)$ at all stations. One standard deviation of mean values plotted. 


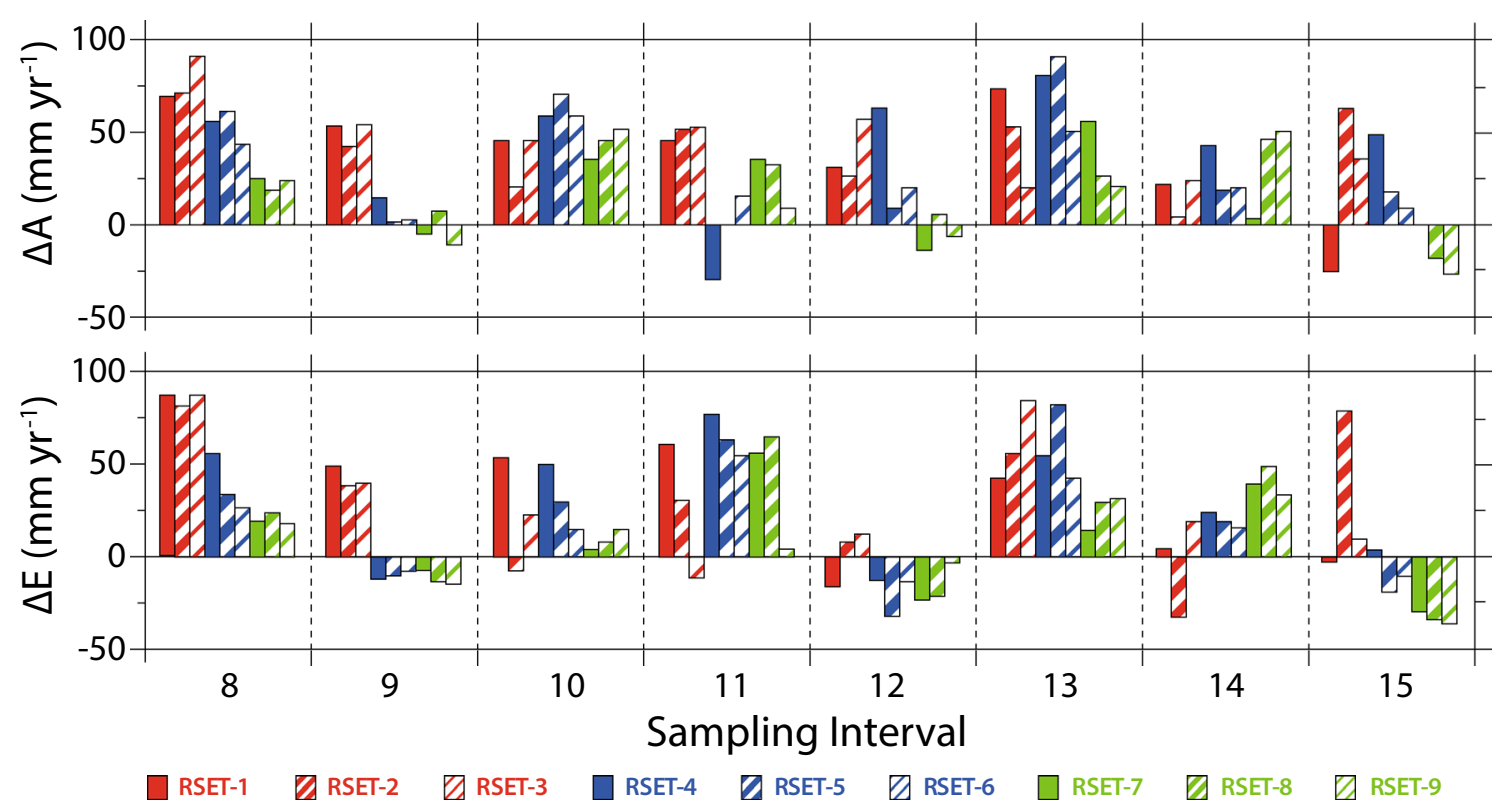

Figure 6. Annualized rates of sediment accretion $(\Delta A)$ and surface-elevation $(\Delta E)$ change for eight survey periods, 1 February 2011 to 29 January 2014 (Figure 3, Drivers). Data used for generalized linear mixed effects and boosted regression tree modelling. Forest zones: fringe (RSET 1 to 3), scrub (RSET 4 to 6), relict fringe (RSET 7 to 9 ).

fringe forest, that averaged $-5 \mathrm{~mm}$ (range: +1.4 to $-16.3 \mathrm{~mm}$ ) and $-7.2 \mathrm{~mm}$ (range: -3.8 to $11 \mathrm{~mm})$, respectively, whereas seasonal net elevation increases $(+11.3$, range: -5.1 to $28.4 \mathrm{~mm})$ occurred in the fringe forest (Figure 6). The seasonal cycle for the entire 9.2-year elevation record had similar average values to the 2011-2014 interval of $+10.2 \mathrm{~mm}$ (fringe), $-8.2 \mathrm{~mm}$ (scrub) and $-7.2 \mathrm{~mm}$ (relict fringe forest). There were, however, larger extremes in the relict fringe forest (that is $-17.7 \mathrm{~mm}, 8$ October 2013 to 29 January 2014).

\section{Shallow Subsidence}

Shallow subsidence rates $\left(S_{\mathrm{S}}, \mathrm{mm} \mathrm{y}^{-1}\right)$ estimated from linear regression analysis of sediment accretion $(\Delta A, 40 \times 40$-cm ceramic plates) and substrate elevation $(\Delta E)$ time series display consistent patterns among and within each forest zones (Figure 5). In the fringe forest, values of $\Delta E$ were similar to $\Delta A$ so that annual rates of shallow subsidence $\left(\sim 3.5-11.9 \mathrm{~mm} \mathrm{y}^{-1}\right)$ were relatively small in comparison to rates of surface-elevation gains (that is, $S_{\mathrm{s}}<\Delta E$ ). Shallow subsidence rates are of similar magnitude in the relict fringe forest $(\sim 6-$ $9 \mathrm{~mm} \mathrm{y}^{-1}$ ), although they are also similar to rates of surface-elevation gain (that is, $S_{\mathrm{s}} \sim \Delta E, \sim 7-$ $\left.9 \mathrm{~mm} \mathrm{y}^{-1}\right)$. Shallow subsidence rates in the scrub forest were highly uniform $\left(\sim 16 \mathrm{~mm} \mathrm{y}^{-1}\right)$ and at RSET- 5 and RSET- 6 were larger than rates of sur- face-elevation gain (that is, $S_{\mathrm{s}}>\Delta E$ ). These results indicate the progressive reduction in $\Delta E$ with distance across the upper-intertidal platform.

\section{Drivers of Sediment Accretion and Elevation Dynamics}

The GAM models fitted by maximum likelihood identified key drivers of sediment accretion and elevation change at RSET stations for two submodels: horizontal distance from un-vegetated mudflat (model 1) and by forest zone (model 2) (Table 1). Functional information from the BRT modelling was used to inform the GAM models (that is, linear/nonlinear).

For model la (Table 1, distance from mudflat), $\Delta A$ was best explained (in order) by mean onshore wind speed and fitting a second-order polynomial to hydroperiod, where higher accretion rates are associated with lower wind speeds and hydroperiods (that is, negative slopes). Mean air temperature (second-order polynomial fit) is an important secondary factor (Table 1), also having a negative slope. The performance of the model with linear fits to hydroperiod and mean air temperature was poor in comparison to the polynomial curves (that is, Hp: $t=2.78, \quad p=0.0074 ; \quad T_{\text {mean }}: \quad t=-0.22$, $p=0.82$ ).

By comparison, $\Delta E$ was described by a simpler model and best explained almost entirely by $T_{\text {mean }}$ (poly degree-2 fit) with hydroperiod being a sec- 
Table 1. Linear and Non-linear Mixed Effects (Distance from Mudflat): Model la-Sediment Accretion $(\Delta A$ $\left.\left[\mathrm{mm} \mathrm{y}^{-1}\right]\right)$ and Model $\mathrm{lb}-$ Elevation Change $\left(\Delta E\left[\mathrm{~mm} \mathrm{y}^{-1}\right]\right)$

\begin{tabular}{|c|c|c|c|c|c|c|}
\hline & Estimate & SE & $d f$ & $t$ & $P$ & SE/estimate \\
\hline \multicolumn{7}{|l|}{ Model la } \\
\hline Intercept & 31.329 & 2.614 & 56 & 11.99 & $<0.0000$ & \\
\hline Hzresid & -0.054 & 0.028 & 56 & -1.96 & 0.0547 & 0.51 \\
\hline$W_{\text {mean }}$ & -105.635 & 25.917 & 56 & -4.08 & 0.0001 & 0.25 \\
\hline Hp (poly-2) & -85.416 & 23.329 & 56 & -3.66 & 0.0006 & 0.29 \\
\hline$T_{\text {mean }}($ poly-2) & -80.246 & 24.427 & 56 & -3.29 & 0.0018 & 0.30 \\
\hline \multicolumn{7}{|l|}{ Model lb: $\Delta E$} \\
\hline Intercept & 3.290 & 6.873 & 60 & 0.48 & 0.6339 & \\
\hline Hp & 1.484 & 0.501 & 60 & 2.96 & 0.0044 & 0.34 \\
\hline$T_{\text {mean }}$ & -94.029 & 27.042 & 60 & -3.48 & 0.0009 & 0.28 \\
\hline$T_{\text {mean }}($ poly-2) & -138.994 & 27.829 & 60 & -4.99 & $<0.0000$ & 0.20 \\
\hline
\end{tabular}

Fit diagnostics. Model 1a: $A I C=-330.6 ;$ BIC $=-305.6 ; \log$ likelihood ratio $=176.3$. Model $1 \mathrm{~b}:$ AIC $=-305.74 ;$ BIC $=-289.81 ; \log$ likelihood ratio $=159.87$.

Model la fixed effects: residuals of linear regression (Hzresid, MFdist $\left.=f\left(h_{\text {mean }}\right)\right) ;$ mean onshore wind speed $\left(W_{\text {mean }}, m s^{-1}\right) ;$ hydroperiod $(H p, \%)$; and mean air temperature $\left(T_{\text {mean }}\right)$ with second-order polynomial fits; Model $1 \mathrm{~b}$-elevation change $\left(\Delta E\left[m m y^{-1}\right]\right)$. Fixed effects: hydroperiod and mean air temperature with second-order polynomial fit.

ondary factor (model $\mathrm{lb}$, Table 1 ). Both $T_{\text {mean }}$ and hydroperiod had a negative slope, with lower elevation gains associated with longer hydroperiods and higher air temperatures. Overall, the AIC/BIC diagnostics and tabulated statistics for both models indicate that model $\mathrm{lb}$ for $\Delta E$ provided a better fit to the data than model la $(\Delta A)$.

For model 2a (forest zone), $\Delta A$ is best explained by mean air temperature ( $T_{\text {mean, }}$ second-order polynomial) and hydroperiod (second-order polynomial), with mean onshore wind speed ( $\left.W_{\text {mean }}\right)$ being a secondary factor (Table 2). Surface-elevation change $(\Delta E$, model $2 \mathrm{~b})$ was again almost entirely explained by $T_{\text {mean }}$ (second-order polynomial, negative slope) and hydroperiod was a secondary factor (Table 2). Forest zone was a redundant factor in both models. Overall, the AIC/
BIC diagnostics and tabulated statistics indicated that model $2 \mathrm{~b}(\Delta E)$ is a better fit to the data than model 2a $(\Delta A)$.

Partial dependency (PD) plots for the final boosted regression tree models (that is, after simplification) provide functional information on the nature of the relationships between each retained predictor variable and the sediment accretion $(\Delta A)$ and surface-elevation change $(\Delta E)$ response variables, as well as their relative influence (RI, Figure 7). These results demonstrate that the performance of the $\Delta E$ model, in terms of \% deviance explained, was substantially better than for the $\Delta A$ model.

The PD plots for $\Delta A$ over the 2011-2014 period for the retained (most influential) predictors indicate nonlinear responses for some predictors (Fig-

Table 2. Linear and Non-linear Mixed Effects (Forest Zone): Model 2a-Sediment Accretion $\left(\Delta A\left[\mathrm{~mm} \mathrm{y}^{-1}\right]\right)$ and Model 2b-Elevation Change $\left(\Delta E\left[\mathrm{~mm} \mathrm{y}^{-1}\right]\right)$

\begin{tabular}{|c|c|c|c|c|c|c|}
\hline & Value & SE & $d f$ & $t$ & $P$ & SE/value \\
\hline \multicolumn{7}{|l|}{ Model 2a: $\Delta A$} \\
\hline Intercept & 185.545 & 36.833 & 58 & 5.04 & $<0.0001$ & \\
\hline$W_{\text {mean }}$ & -36.179 & 8.618 & 58 & -4.20 & 0.0001 & 0.24 \\
\hline Hp (poly-2) & -80.841 & 23.563 & 58 & -3.43 & 0.0011 & 0.29 \\
\hline$T_{\text {mean }}($ poly-2) & -85.694 & 23.477 & 58 & -3.65 & 0.0006 & 0.27 \\
\hline \multicolumn{7}{|l|}{ Model 2b: $\Delta E$} \\
\hline Intercept & 3.290 & 6.873 & 60 & 0.48 & 0.6339 & \\
\hline Нp & 1.484 & 0.501 & 60 & 2.96 & 0.0044 & 0.34 \\
\hline$T_{\text {mean }}($ poly-2) & -138.994 & 27.829 & 60 & -4.99 & $<0.0001$ & 0.20 \\
\hline
\end{tabular}



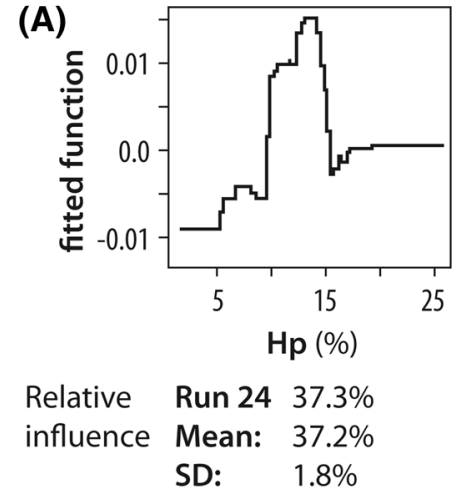

(B)

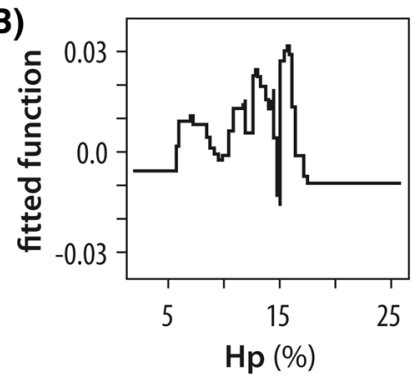

$\begin{array}{lll}\text { Relative } & \text { Run } 23 & 35.8 \% \\ \text { influence } & \text { Mean: } & 35.8 \% \\ & \text { SD: } & 0.6 \%\end{array}$

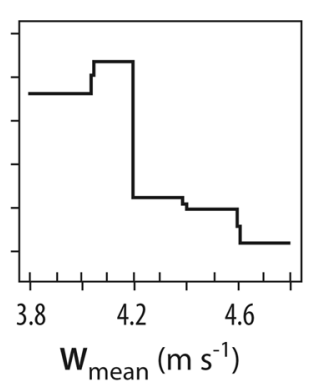

$26.6 \%$

$26.6 \%$

$1.1 \%$

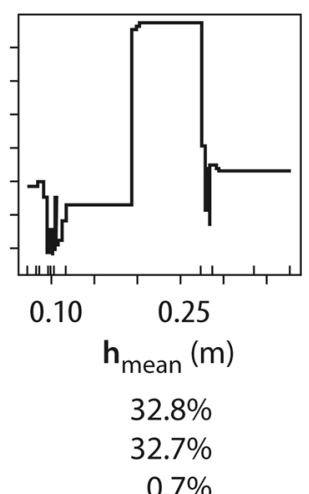

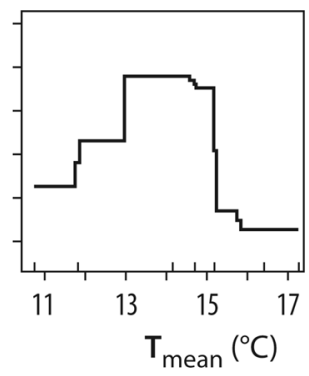

$21.4 \%$

$20.6 \%$

$1.1 \%$

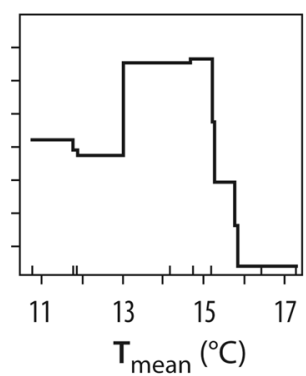

$31.5 \%$

$31.5 \%$

$0.7 \%$

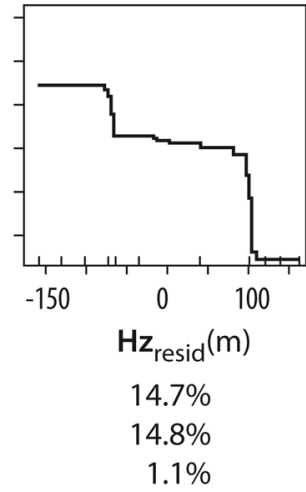

$1.1 \%$

Figure 7. A Sediment accretion $(\Delta A)$ and $\mathbf{B}$ surface-elevation change $(\Delta E)$ models: partial dependency plots of retained predictors from analysis of model deviance and their relative influence (RI) on $\Delta A$ and $\Delta E$. Shown are results for model runs $24(\Delta A)$ and $23(\Delta E)$, which are the closest matches to the mean RI values for the model runs. Model settings: Tree complexity $=1$; learning rates $=0.005(\Delta A)$ and $0.01(\Delta E)$; bag fraction $=0.5$; data type-Gaussian. Mean cross-validation deviance and (SE): $0.00053\left(\Delta A=7.8 \times 10^{-5}, \Delta \Delta E=1.16 \times 10^{-4}\right)$. Number of trees fitted: $1,200-3,400(\Delta A)$ and 3,3509,350 $(\Delta E)$. Model performance: $(\Delta A)$ mean total deviance $($ MTD $)=7.9 \times 10^{-4}$, mean cross-validated deviance $(\mathrm{CVD})=5.2 \times 10^{-4}, \quad \%$ deviance explained $=34 \% ; \quad(\Delta E) \quad$ MTD $=10.9 \times 10^{-4}, \quad$ CVD $=5.3 \times 10^{-4}, \quad \% \quad$ deviance explained $=52 \%$.

ure 7A). Hydroperiod was the single most important predictor of $\Delta A$ (mean RI $\sim 37 \%$ ). Most sediment accretion occurred at hydroperiods of 10$15 \%$ duration. Longer hydroperiods did not substantially increase sediment accretion. Mean onshore wind speed was the next most influential predictor of $\Delta A$ (mean RI $\sim 27 \%$ ). The partial response of $\Delta A$ indicates that most sediment accretion occurs at $W_{\text {mean }}$ values of $3.8-4.2 \mathrm{~m} \mathrm{~s}^{-1}$. The abrupt decline in the response of $\Delta A$ to $W_{\text {mean }}$ suggests a threshold in rate of sediment supply from the unvegetated mud flats at $W_{\text {mean }} \sim 4.2$ $\mathrm{m} \mathrm{s}^{-1}\left(15 \mathrm{~km} \mathrm{~h}^{-1}\right)$. Mean air temperature is the third most influential predictor of $\Delta A$, (mean RI $21 \%$ ) with most sediment accretion occurring at $T_{\text {mean }}$ of $\sim 13-15^{\circ} \mathrm{C}$.

The derived variable $\mathrm{Hz}_{\text {resid }}$ (that is, residuals of linear regression of MFdist with $h_{\text {mean }}$ permitting analysis of distance from mudflat independent of mean water depth) accounted for a relatively small proportion of the $\Delta A$ response (mean RI $\sim 15 \%$ ). (Supplementary Information).

The partial responses of surface-elevation change $(\Delta E)$ are split almost evenly between the three most influential retained predictors, being hydroperiod, mean water depth and mean air temperature (Figure 7B). The response of $\Delta E$ to hydroperiod is similar to $\Delta A$, although noisier, with most sediment accretion coinciding with hydroperiod of $10-17 \%$ (mean RI $=36 \%$ ). Likewise, longer hydroperiods did not substantially influence sediment accretion.

Mean water depth was the next most influential predictor of $\Delta E$ (mean RI $\sim 33 \%$ ). The partial response of $\Delta E$ indicates that most sediment accretion occurs at mean water depths of 0.2 to $0.3 \mathrm{~m}$. Some linear interaction between mean water depth and hydroperiod is indicated by their correlation (adjusted $r^{2}=0.32$, Supplementary Information). The similarity of the partial dependency plot for 
hydroperiod with $\Delta A$ suggests that this interaction is minor (Figure 7A). The PD plot also indicates that mean air temperature is correlated with a process that influences surface-elevation changes at the RSET stations (mean RI $\sim 32 \%$ ). As also observed for $\Delta A$, most surface-elevation response coincides with $T_{\text {mean }}$ of about $13-15^{\circ} \mathrm{C}$, with no response above $16^{\circ} \mathrm{C}$ (Figure 7B).

\section{Sediment Properties and Root Growth}

The physical properties of sediments deposited at the RSET stations (February 2007-June 2013) display subtle differences between the three forest zones. Sediments rapidly accumulating in the fringe forest are homogeneous with depth and between RSET benchmarks, with mean dry bulk densities and porosities of $0.48 \pm 0.04 \mathrm{~g} \mathrm{~cm}^{-3}$ and $0.85 \pm 0.05 \mathrm{~g} \mathrm{~cm}^{-3}$, respectively (Supplementary Information). Dry bulk sediment densities in the scrub forest showed apparent increases with depth at RSET-5 and RSET-6 $\left(0.01-0.02 \mathrm{~g} \mathrm{~cm}^{-3} / \mathrm{cm}\right.$, $\left.r^{2}=0.6,0.68, P<0.02\right)$ and distance across the upper-intertidal platform. Dry bulk densities were lowest in the relict fringe forest (range: 0.34$0.55 \mathrm{~g} \mathrm{~cm}^{-3}$ ). The sediments deposited at the RSET stations are also largely composed of mineral particles, with organic content being less than $15 \%$. Organic matter contents of sediments in the fringe and scrub forest zones are lower and less homogenous (range: 6.4-14\%) than in the relict fringe forest (range: 9-14\%).

Root biomass production measured over 12 months in the top-most $0.15-0.23 \mathrm{~m}$ of the substrate varied between forest zones. The volume of root material produced was a very small fraction of the sediment volume $(\leq 0.6 \%)$. Mean root production as dry mass (MRP, $\mathrm{g} \mathrm{m}^{-2} \mathrm{y}^{-1}$ ) in the fringe forest $\left(\sim 50 \mathrm{~g} \mathrm{~m}^{-2} \mathrm{y}^{-1}\right)$ was 1.4- to threefold higher than in the scrub and relict fringe forests, respectively (Figure 8 ). The nested ANOVA $(\alpha=0.05)$ analysis confirmed that mean cube-root transformed production varied significantly between forest zones but not among RSET stations within each forest zone.

\section{Discussion}

\section{Sediment Accretion Patterns}

Sediment accretion in the Firth mangrove forest is controlled by the coupling of frequent onshore winds and resulting resuspension of intertidal muds by small estuarine waves, with the fortnightly cycle of spring tide inundation. These coupled processes regularly deliver fine fluvial muds sequestered in

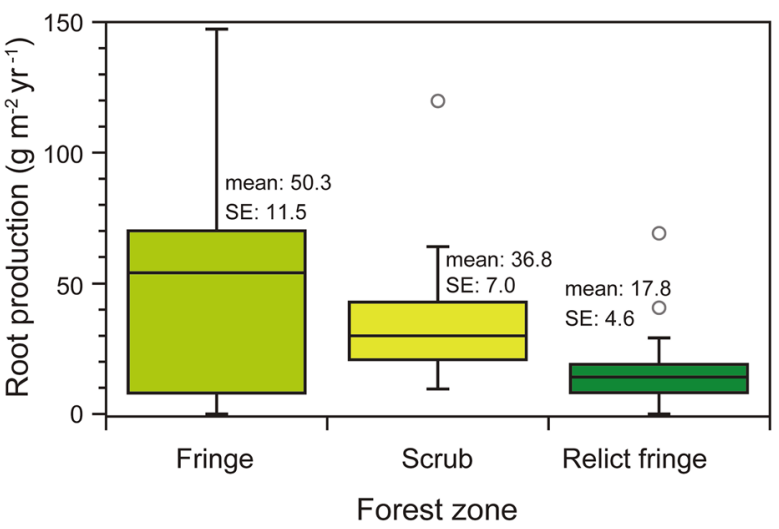

Figure 8. Root production $\left(\mathrm{g} \mathrm{m}^{-2} \mathrm{y}^{-1}\right)$ in the fringe, scrub and relict fringe forest zones measured over a 12 month period, 6 March 2012-12 March 2013.

unvegetated mudflats to the fringe forest, scrub and relict fringe forests on the upper-intertidal platform and resulting rapid accretion (13 to $47 \mathrm{~mm} \mathrm{y}^{-1}$ ). Sediment accretion rates of $13-47 \mathrm{~mm} \mathrm{y}^{-1}$ observed in the Firth mangrove forest (Figure 5) are among the highest measured in the largely fluvial sediment-dominated mangrove forests of the IndoPacific region (Lovelock and others 2015b; Sidik and others 2016). Sediment accretion rates varied among forest zones, being highest in the fringe forest in the mid-intertidal zone $\left(37-47 \mathrm{~mm} \mathrm{y}^{-1}\right)$ and lowest in the infrequently inundated relict fringe forest $\left(13-18 \mathrm{~mm} \mathrm{y}^{-1}\right)$ on the upper-intertidal platform. In between, sediment accretion rates in the scrub forest progressively decreased (38 to $27 \mathrm{~mm} \mathrm{y}^{-1}$ ) with distance from the unvegetated mudflat. This pattern of sediment accretion in the scrub forest is consistent with progressive deposition of fine sediment from suspension as springflood tides inundate the vegetated platform. Stokes Law yields a settling velocity estimate of $\sim 0.04$ $\mathrm{cm} \mathrm{s}^{-1}$ (that is, particle density $\sim 2.65 \mathrm{~g} \mathrm{~cm}^{-3}$ ) for these uniformly fine muds (mean/median diameter $\sim 20 \mu \mathrm{m}$, Swales and others 2015). Suspended mud advected into the forest therefore has the potential to be deposited, as complete settling would theoretically occur (that is, spherical particles in a laminar flow) within about 20 and about 4 minutes, respectively, under maximum and mean spring tide water depths of 0.5 and $0.1 \mathrm{~m}$. Deposition of clay particles less than $4 \mu \mathrm{m}$ diameter is also likely to be enhanced by flocculation during slack high tides when turbulence is reduced (Furukawa and others 1997). Recent measurements using image analysis methods indicate that flocculation of fine suspended particles does occur in the mangrove forest (unpublished data, Iain MacDonald, 
NIWA). These considerations suggest that physical processes, in the absence of biophysical feedbacks, can explain the sedimentation patterns observed in the mangrove forest over seasonal-to-annual timescales, as well as over decadal timescales (Swales and others 2015).

Modelling of sediment accretion $(\Delta A)$ patterns using a range of potential meteorological and oceanographic predictor variables provided insights into the main drivers of sedimentation in the mangrove forest. The maximum likelihood GAM results indicate that onshore wind speed $\left(W_{\text {mean }}\right)$ and quadratic functions of hydroperiod and mean air temperature were the main drivers of sediment accretion in the mangrove forest. These findings are supported by the optimized BRT partial dependency plots (Figure 7A). The BRT modelling similarly indicated a nonlinear (that is, quadratic) response of $\Delta A$ to hydroperiod and mean air temperature. The strongest response to hydroperiod occurred at values of $10-15 \%$ duration, which coincided with the fringe and scrub forest zones. So, although hydroperiods were substantially longer in the relict fringe forest due to ponding, a large fraction of the suspended sediment advected into the forest from the mud flat had already been deposited. The functional response of $\Delta A$ to hydroperiods greater than $15 \%$ remained relatively strong. This suggests that ponding in the relict fringe forest over multiple tidal cycles was an effective mechanism for trapping of any fine sediments that remained in suspension. Ponding occurred primarily due to the low permeability of the mud substrate and limited water-carrying capacity of the small relict creeks such that drainage of the large volumes of turbid spring tide water delivered to the relict fringe forest as sheet flow was ineffective (Swales and others 2015). The BRT modelling also indicated that mean onshore wind speeds were a significant factor driving sediment accretion in the mangrove forest $(\mathrm{RI}=27 \%)$. The partial dependency plot indicates a threshold onshore wind speed of about $4.2 \mathrm{~m} \mathrm{~s}^{-1}$ (Beaufort scale: gentle breeze), above which the influence of this factor on $\Delta A$ was much reduced.

Sediment accretion rates of $\sim 10-50 \mathrm{~mm} \mathrm{y}^{-1}$ observed at RSET stations in our study indicate substantial onshore fluxes of mud from the unvegetated intertidal flat. GAM and BRT analyses of meteorological and oceanographic time series with $\Delta A$ suggest that these onshore mud fluxes and delivery to the forest are driven by wave resuspension of mud under frequently occurring onshore wind conditions coinciding with spring tides rather than episodic storm tides, as expected from previous studies of sediment resuspension and transport on estuarine intertidal flats (Christie and others 1999; McAnally and others 2007; Talke and Stacey 2008; van Maren and Winterwerp 2013; Green and Coco 2014). In the context of a wave-dominated estuary, the threshold onshore wind speed of around $4.2 \mathrm{~m} \mathrm{~s}^{-1}$ indicated by the BRT partial dependency plot (Figure 7A) suggests that: (1) small waves generated by onshore sea breezes blowing across a large fetch (that is, $30+\mathrm{km}$ ) are sufficient to exceed the critical bed shear stress $\left(\tau_{\text {crit. }}\right)$ for resuspension of surficial muds, consistent with Mariotti and Fagherazzi (2013); and (2) small waves generate substantial onshore mud fluxes as inferred from sediment accretion rates in the mangrove forest. Support for this inferred sediment resuspension threshold is provided by an analysis of wind speed and suspended sediment concentration (SSC) data from the present study site (Balke and others 2015). Their analysis of a 9-month optical backscatter sensor record from the fringe forest near RSET-2 (Figure 2) showed that SSC was close to the maximum recorded approximately 1,200 $\mathrm{mg}^{-1}$ value on $95 \%$ of days when maximum onshore wind speed exceeded $5 \mathrm{~m} \mathrm{~s}^{-1}$. Additionally, Mariotti and Fagherazzi (2013) observed on intertidal mudflats with a similar fetch length (that is, $20 \mathrm{~km}$ ) that maximum bed shear stress occurred in water depths of less than one meter for wind speeds of $5 \mathrm{~m} \mathrm{~s}^{-1}$. Observations of intertidal flat sediment dynamics in estuaries neighbouring our study site also show that small estuarine waves generated by gentle-to-moderate winds drive fine-sediment transport. Resuspension is modulated by tidal cycle variations in fetch and water depth that in turn control wave growth and decay (Green and others 1997; Swales and others 2004; Green and Coco 2007; Green 2011).

Previous studies have sought to link meteorological and oceanographic processes with sediment accretion in mangrove forests. In Moreton Bay (Queensland, Australia), Lovelock and others (2015a) found that sediment accretion was correlated with both sea-level anomalies (that is, relative to mean sea level [MSL]) and water turbidity. In turn, the MSL anomaly and cumulative rainfall had a significant positive relationship with water turbidity near major river outlets in western Moreton Bay. Silt plumes from these rivers as well as resuspension of intertidal sediments were identified as likely drivers of water turbidity that drive sediment accretion in these mangrove forests. In the Hunter River estuary (New South Wales, Australia), Rogers and others (2013) investigated the contribution of storm discharges from rivers and storm tides to sediment accretion in mangrove forest and salt marsh. The effects of these storms on sediment accretion 
were relatively short lived and did not substantially influence inter-annual accretion trends in the mangrove forest (Rogers and others 2013). Similarly, in our study, storm tides were not significant drivers of sediment accretion, as identified by modelling. Storm discharges from rivers were also infrequent and, unless coincident with spring high tides, unlikely to substantially influence sedimentation in the mangrove forest (Figure 4). In the Firth, sediment accretion in the mangrove forest is driven by the coupling of frequent wind-driven sediment resuspension on the mudflats by waves (that is, supply) with the fortnightly cycle of spring tides that control hydroperiod and resulting sediment delivery. Leonardi and others (2016) investigated the influence of wave power on salt marsh erosion rates at eight sites on the USA East Coast and Gulf of Mexico. Wave power and return period were estimated for a range of meteorological conditions over a 23-year record. Long-term erosion rates for salt marsh at these sites were derived from published datasets and measurements. The record included storm and hurricane events. Leonardi and others (2016) found a significant linear relationship between salt marsh erosion rates and event wave power, made non-dimensional by the average conditions at each site. They concluded that salt marsh erosion rates were controlled by moderate storms with return periods of several months, with extreme storms contributing less than one per cent to the observed long-term erosion rates.

These findings are similar to our study of the Firth of Thames mangrove forest in that it is the more frequent "day-to-day" processes, rather than extreme events, that drive the long-term biogeomorphic response of coastal wetlands to environmental conditions. This reflects the fact that storm surges on the New Zealand coast are relatively small (Bell and others 2000) and river floods are infrequent. The relative unimportance of these drivers is exacerbated by the position of the mangrove-forest platform in the upper-intertidal zone, so that these episodic events must coincide with spring high tides to be effective sediment delivery mechanisms. By contrast, wave-driven resuspension of intertidal sediments and resulting "turbid fringe" is a ubiquitous feature of New Zealand estuaries (Green and Coco 2014). The dominance of the long-term biogeomorphic response to wave-driven sediment resuspension by onshore winds reflects the much higher frequency of occurrence of wind-driven sediment resuspension compared to storm events.

Mean air temperature $\left(T_{\text {mean }}\right)$ was identified in our study as an influential predictor of sediment accretion in the mangrove forest (that is, $\Delta A \sim$
$T_{\text {mean }}^{2}$ ). In particular, the partial dependency plot (Figure 7A) indicated that most sediment accretion occurred at $T_{\text {mean }}$ of $13-15^{\circ} \mathrm{C}$, with accretion being minimal at higher air temperatures. Inspection of the data shows that a seasonal "low accretion" response coincided with the summer months. Similar patterns of response to $T_{\text {mean }}$ were identified by the BRT model for surface-elevation changes (Figure 7B). A potential mechanism for these responses is seasonal compaction of the clay-rich surficial muds that is directly related to seasonal changes in air temperature. Specifically, surficial sediment desiccation increases at higher air temperatures during summer months, coupled with infrequent tidal inundation of the upper-intertidal platform.

The least influential predictor of sediment accretion that was retained in the BRT model was the derived predictor $\mathrm{Hz}_{\text {resid }}(\mathrm{RI} \sim 15 \%$, Figure $7 \mathrm{~A}$ ), which indicated that the largest reduction in sediment accretion with distance from the unvegetated mudflat occurred in the scrub forest in mean water depths of less than $0.12 \mathrm{~m}$. This finding is consistent with the rapid settling of suspended muds as spring-flood tides inundate the upper-intertidal platform and resulting accretion patterns (Figure 5).

\section{Processes Driving Surface-Elevation Trends}

Rates of surface-elevation gain observed in our study over the entire 9.2 -year record $\left(8-35 \mathrm{~mm} \mathrm{y}^{-}\right.$ $\left.{ }^{1}\right)$ are among the highest reported in a mangrove forest. These linear trends are consistent with a longer-term record of surface-elevation trajectory over the last century of the tidal flat and evolving mangrove forest, provided by ${ }^{210} \mathrm{~Pb}$ geochronology (Swales and others 2015). The low-permeability mud deposits are weakly consolidated so that ${ }^{210} \mathrm{~Pb}$ sediment accumulation rates (SAR) could be used as a proxy for surface-elevation gain. The resulting geomorphic reconstruction by Swales and others (2015) in the relict fringe forest showed that surface-elevation gain displayed an asymptotic trajectory, initially rapidly gaining elevation (25$77 \mathrm{~mm} \mathrm{y}^{-1}$ ) as muds deposited on the former intertidal sand flats in the early-1950s. Surface-elevation gain declined $\left(10 \mathrm{~mm} \mathrm{y}^{-1}\right)$ as the mangrove forest platform reached the upper limit of the tidal frame in the late-1970s. Rates of elevation gain are ultimately limited by the formation of new sediment accommodation space by sea-level rise and subsidence of the underlying sedimentary basin (Swales and others 2016). Our RSET measure- 
ments incorporate the full range of geomorphic development, from the rapidly accreting fringe forest located in the mid-intertidal to the relict fringe forest on the upper-intertidal platform.

Biophysical processes controlling surface-elevation dynamics in the mangrove forest include surface as well as subsurface processes. The importance of wind-driven resuspension of sediment by small waves on the unvegetated mudflat as the primary supply mechanism is inferred from the GAM and BRT results. Significant reductions in accretion rates across the scrub forest platform are consistent with settling of muds from suspension during spring-flood tides. In the fringe forest, $\Delta A$ was approximately the same as $\Delta E$ so that sediment accretion is the major process driving surface-elevation dynamics in that environment (Figure 5). By contrast, the contribution of root production to surface-elevation gains in the Firth of Thames $A$. marina mangrove forest appears to be negligible. Highest mean root production (MRP) of $50 \mathrm{~g} \mathrm{~m}^{-}$ ${ }^{2} \mathrm{y}^{-1}$ (Figure 8) occurred in the fringe forest, contributing less than $1 \%$ of the post-2009 sedimentation volume. Lovelock and others (2015a) measured MRP along with surface-elevation trends in the A. marina forests fringing the muddy western shores of Moreton Bay. MRP of about $130 \mathrm{~g} \mathrm{~m}^{-}$ ${ }^{2} y^{-1}$, measured over two successive years, were twofold higher than in the Firth mangrove forest. In the Rhizophora stylosa-dominated forests of eastern Moreton Bay MRP of about $600 \mathrm{~g} \mathrm{~m}^{-2} \mathrm{y}^{-1}$, were substantially higher; however, no significant relationship was found between MRP and surfaceelevation gains. McKee (2011) measured MRP of about $80-800 \mathrm{~g} \mathrm{~m}^{-2} \mathrm{y}^{-1}$ in the Rhizophora mangle forests of Belize and Florida. Surface-elevation trends of -5.4 to $10.9 \mathrm{~mm} \mathrm{y}^{-1}$ in these $R$. mangle forests were positively correlated with, and significantly influenced by, root production. These data suggest that root production may not substantially influence surface-elevation dynamics in the fluvial sediment-dominated Avicennia marina forests of Australasia.

Shallow subsidence $\left(S_{\mathrm{S}}\right)$ rates inferred from the elevation and accretion measurements were highest and most uniform in the scrub forest $\left(S_{\mathrm{S}}=15.8-\right.$ $16.4 \mathrm{~mm} \mathrm{y}^{-1}$ ) and lowest and most variable in the fringe forest $\left(S_{\mathrm{S}}=3.5-11.9 \mathrm{~mm} \mathrm{y}^{-1}\right)$ where muds are rapidly accumulating (Figure 6). In the relict fringe forest, $S_{\mathrm{S}}$ of $5.8-9.3 \mathrm{~mm} \mathrm{y}^{-1}$ are similar to the fringe forest but less variable. These results are contrary to the review of Cahoon and others (2006), who concluded that net surface-elevation changes in more peat-dominated mangrove systems are mostly negative due to shallow subsidence and that subsidence rates were highest at sites with the highest sedimentation rates. More recently, Lovelock and others (2015b) analysis of more than 150 SET stations in the Indo-Pacific (including data from our study site) showed that rates of surfaceelevation gain at $69 \%$ of sites were less than RSLR. In many cases, this was partly attributable to shallow subsidence.

The most influential predictors (in almost equal measure) of surface-elevation dynamics in the Firth mangrove forest, inferred from BRT models, were hydroperiod $(\mathrm{RI}=36 \%)$, mean water depth $(\mathrm{RI}=33 \%)$ and mean air temperature $(\mathrm{RI}=31 \%)$ (Figure 7). These results suggest that, unlike accretion, surface-elevation dynamics are driven by: (1) in situ processes; and (2) partly by the balance between fortnightly inundation by spring tides and seasonal cycles of wetting and drying of surficial muds that controls $S_{\mathrm{S}}$ rates. Consequently, most surface-elevation gain occurs at lower mean air temperatures (that is, $<15^{\circ} \mathrm{C}$ ), during the autumn-winter when desiccation is reduced compared to the summer months.

Mean statistics mask the large diurnal variations in air temperature during the summer when sediment desiccation occurs. Examination of the elevation seasonal time series (2011-2013) shows a winter-summer cycle of elevation loss in the scrub and relict fringe forests, averaging 5-7 mm (maximum: $-16 \mathrm{~mm}$ ), where tidal inundation is infrequent. As described for the sediment accretion response, surface compaction due to sediment desiccation is directly related to higher mean temperatures that occur in the summer. The smectite clay-rich muds of the southern Firth (Naish and others 1993) are susceptible to shrinkage and swelling due to their high plasticity index and low shrinkage limit (Mitchell 1993; Yesiller and others 2000). Desiccation and resulting sediment compaction is a diagnostic feature of water-saturated intertidal mudflats and coastal wetlands that are regularly subaerially exposed and is exacerbated under high-salinity conditions (for example, Reineck and Singh 1980; Plummer and Gostin 1981; Allen 2000), such as occur in the Firth mangrove forest muds (that is, 30-55 PSU, Lovelock and others 2010). Sediment compaction-by-desiccation/dehydration during the summer months is also likely promoted by forest transpiration, higher air temperatures and wind speeds (Coelho and others 2009). Infiltration and rapid rehydration of sediments is also promoted by desiccation cracks (Baer and others 2009). In the Firth, the shrinkswell cycle due to desiccation, compaction and rehydration results in changes in surficial sediment 
volumes and resulting shallow subsidence. This process seasonally modulates surface elevations in the infrequently inundated scrub and relict fringe forests. This shrink-swell process differs fundamentally from the shrink-swell behaviour reported in coastal wetland sediments due to fluctuations in groundwater storage associated with tidal cycle recharge and discharge and climate variability (Cahoon and others 1999, 2009, 2011; Whelan and others 2005; Rogers and others 2005a, 2008).

Surface-elevation dynamics in mangrove forests can also be influenced by deep subsidence $\left(S_{\mathrm{D}}\right)$ (Cahoon and Lynch 1997; McKee and others 2007; Cahoon and Guntenspergen 2010; Swales and others 2016; Woodroffe and others 2016). Deep subsidence was established with campaign-GPS surveys of RSET benchmarks (2007-2016) and ${ }^{210} \mathrm{~Pb}$ geochronology to determine $S_{\mathrm{D}}$ at our study site (Swales and others 2016). This approach enables the contribution of vertical land motion to surface-elevation dynamics in the mangrove forest to be evaluated. These measurements indicated that the forest is subsiding at a relatively uniform rate, averaging $8.8 \pm 0.3 \mathrm{~mm} \mathrm{y}^{-1}$ (range: 7.7$9.4 \mathrm{~mm} \mathrm{y}^{-1}$ ) since at least the late-1960s. Thus, $S_{\mathrm{D}}$ accounts for approximately $80 \%$ of the RSLR in the mangrove forest (Swales and others 2016).

The key physical drivers of sediment accretion, surface-elevation dynamics (identified in our study) and ultimately the biogeomorphic evolution of the southern Firth mangrove forest (Swales and others 2015, 2016) are summarized in Figure 9. This shows the spatial patterns of surface-elevation change, shallow and deep subsidence, and resulting net rate of elevation change relative to sea level $\left(\Delta E_{\text {wet }}\right)$ across the mangrove forest platform. The $\Delta E_{\text {wet }}$ measure (Swales and others 2016), adapted from Cahoon (2015) accounts for site-specific RSLR rather than adopting regional estimates from tide gauges, for example. We adopt a RSLR estimate based on ${ }^{210} \mathrm{~Pb}$ SAR $\left(9.3 \mathrm{~mm} \mathrm{y}^{-1}\right)$, which is within the range of $S_{\mathrm{D}}$ values derived from the campaignGPS measurements (7.7 to $9.4 \mathrm{~mm} \mathrm{y}^{-1}$ ) (Swales and others 2016). Net surface-elevation trends highlight differences in the relative importance of spatially varying shallow subsidence and the relatively uniform deep subsidence in each forest zone. In the rapidly accreting fringe forest, deep subsidence accounts for a greater fraction of net elevation change than does shallow subsidence $\left(\Delta E_{\text {wet }}=23\right.$ to $\left.28 \mathrm{~mm} \mathrm{y}^{-1}\right)$. In the scrub forest, shallow subsidence associated with seasonal desiccation and compaction of surficial sediments is an important process and $\Delta E_{\mathrm{wet}}=2$ to $13 \mathrm{~mm} \mathrm{y}^{-1}$. In the relict fringe forest, shallow and deep subsidence rates are similar and near-equivalent to rates of surface-elevation gain so that net elevation increases are close to zero. Net surface-elevation gain in the relict fringe forest is largely controlled by creation of new accommodation space associated with RSLR, most of which is due to deep subsidence (Swales and others 2016).

\section{Conclusions}

Sediment accretion in the Firth mangrove forest is controlled by the coupling of frequent onshore winds, and resulting resuspension of intertidal muds by small estuarine waves, with the fortnightly cycle of spring tide inundation. These coupled processes regularly deliver fine fluvial muds sequestered in unvegetated mudflats to the fringe forest, scrub and relict fringe forests on the upperintertidal platform and resulting rapid accretion (13 to $47 \mathrm{~mm} \mathrm{y}^{-1}$ ). Our analysis also showed that neither episodic and short-lived flood discharges from rivers nor elevated sea levels during storms significantly influence sediment accretion in the mangrove forest. In turn, net surface-elevation trends ( 0 to $28 \mathrm{~mm} \mathrm{y}^{-1}$ ) were dominated by the physical processes of sediment accretion, shallow subsidence due to seasonal desiccation and resulting compaction of the infrequently inundated forest platform (4 to $16 \mathrm{~mm} \mathrm{y}^{-1}$ ), and deep subsidence of the entire forest (7.7 to $9.4 \mathrm{~mm} \mathrm{y}^{-1}$ ), primarily due to compaction of the underlying sedimentary basin. Thus, it is regular "day-to-day" processes, rather than extreme events, that are important for the delivery of sediments and maintenance of mangrove forest elevation within the intertidal zone. Ultimately it is the coupled processes of intertidal mud resuspension by frequent onshore winds with regular spring tide inundation that drives the long-term biogeomorphic evolution of the mangrove forest.

\section{ACKNOWLEDGEMENTS}

We thank Drs. Glenn Guntenspergen and Beth Middleton (US Geological Survey), Scott Stephens (NIWA) and the journal reviewers for their constructive comments on the manuscript. Data collection involved gruelling hours of field work, with the able assistance of Dr. Vernon Pickett (Waikato Regional Council, WRC), Dr. Catherine Beard (Department of Conservation), Doug Stewart, Daniel Tait (WRC) and Ron Ovenden, George Payne, Kerry Costley, Ben Robinson and Kelly Carter (NIWA). Max Oulton drafted Figures 1, 2, 7 and 9. Elements of Figure 9 were reproduced and modi- 

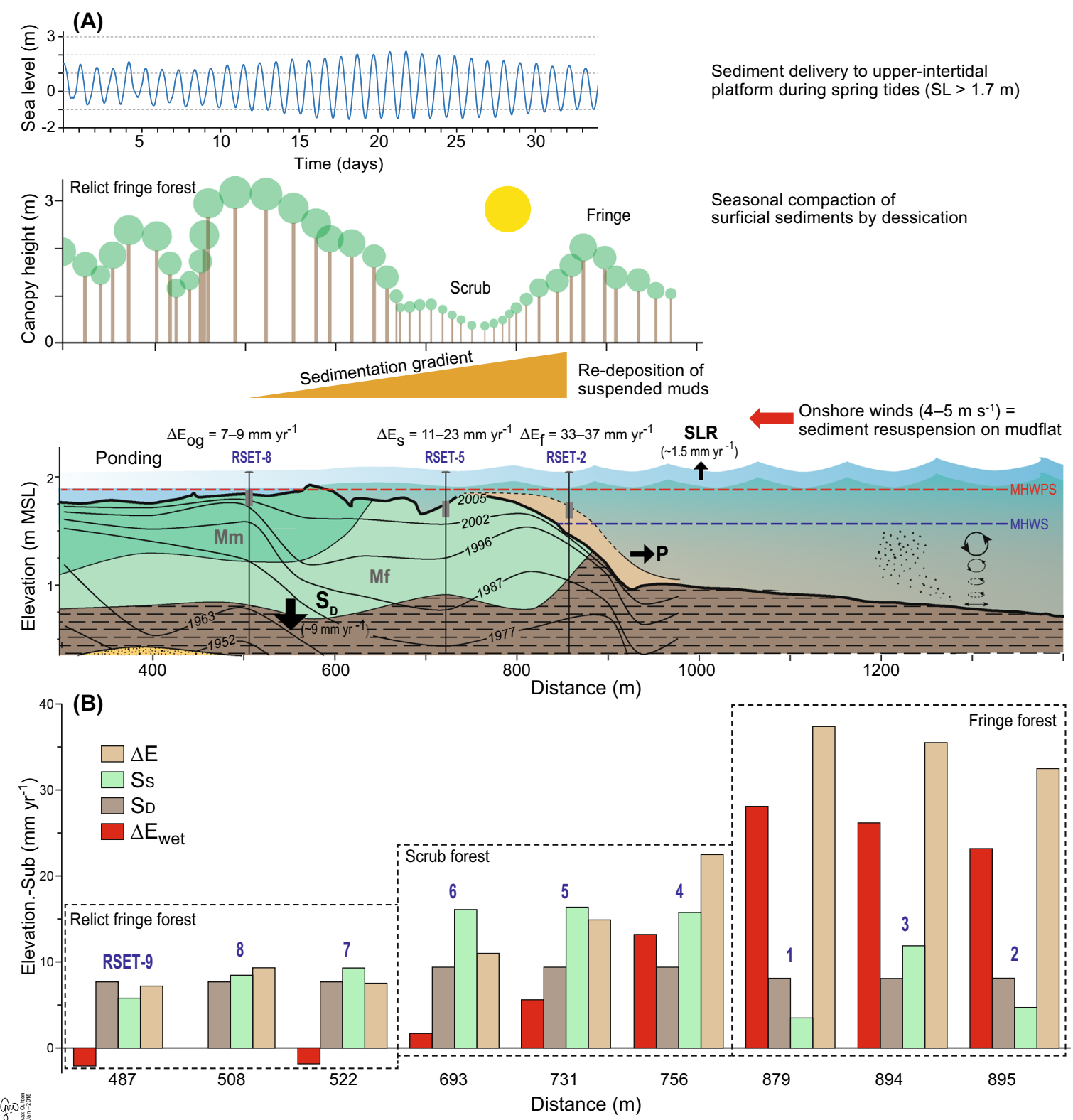

Distance $(m)$

Sediment delivery to upper-intertidal platform during spring tides $(\mathrm{SL}>1.7 \mathrm{~m})$

Seasonal compaction of surficial sediments by dessication

Figure 9. A Conceptual model of sedimentation and surface-elevation dynamics and their key drivers in a wavedominated, fluvial sediment-rich mangrove forest, Firth of Thames, New Zealand. Muds sequestered in intertidal deposits are resuspended and delivered to the forest by spring tides coupled with small, short-period waves generated by frequent onshore winds. Settling of muds from suspension drives a sedimentation gradient across the upper-intertidal flat platform, particularly in the scrub forest. Rates of surface-elevation gain $(\Delta E)$ in the fringe (f), scrub (s) and relict fringe (rf) forests reflect the balance between sediment accretion, deep subsidence $\left(S_{D}\right)$ and shallow subsidence $\left(S_{S}\right)$ of surficial sediments. On the upper-intertidal platform, $\mathrm{S}_{\mathrm{S}}$ is partly driven by a seasonal cycle of desiccation and compaction during summer months and rehydration in the autumn-winter. Progradation $(\mathrm{P})$ of the mangrove forest complex since $\sim 2005$ is driven by rapid infilling of available accommodation space created by $S_{D}$ and sea level rise (SLR). Sedimentary facies: partially bioturbated muds with rare silt laminae (unvegetated mudflats, brown) overlay bioturbated muds with mangrove roots (Mf); and nodular-bioturbated muds with abundant mangrove roots and precipitates (Mm). Isochrones: substrate surface elevations (1952-2005) based on radioisotope dating of cores and RSET data. Biogeomorphic reconstruction adapted from Swales and others 2015, 2016). B Summary of trends in surface-elevation dynamics $\left(2009-2016, \mathrm{~mm} \mathrm{y}^{-1}\right)$ at RSET stations: surface-elevation $(\Delta E), \mathrm{S}_{\mathrm{S}}, \mathrm{S}_{\mathrm{D}}$ and net rate of change in substrate elevation relative to long-term relative SLR $\left(\Delta E_{\text {wet }}\right)$. Notes: (1) RSLRsed is the weighted-average post-1960s ${ }^{210} \mathrm{~Pb} \mathrm{SAR}$ in the relict fringe mangrove forest $\left[9.3 \mathrm{~mm} \mathrm{y}^{-}\right.$ i; (2) $S_{D}$ based on campaign-GPS trends for primary RSET benchmarks in each forest zone (Swales and others 2016)]. 
fied from Swales A, Denys P, Pickett VI, Lovelock CE. (2016). Marine Geology 38: 205-218. Copyright (C) Elsevier. Dr. Ruth Reef (The University of Queensland) provided advice on the processing of root ingrowth bags. Ashvini Victor (NIWA intern) digitized staff gauge images of water levels at RSET stations. Andrew Swales thanks Dr. John Leathwick for providing advice on Boosted Regression Tree analysis. This study was supported by the New Zealand Ministry of Business, Innovation and Employment (contracts C01X1225, C01X0307 and C01X1005, FWCE1706, FWCE1710 and FWCE1811 [Managing Mud Program]) and Waikato Regional Council. Support for Don Cahoon and SET equipment was provided by the USGS, Ecosystems Mission Area. The use of trade names is for descriptive purposes only and does not represent endorsement by the US Government. Historical aerial photography of the southern Firth of Thames was provided by Waikato Regional Council from various sources.

\section{OPEN ACCESS}

This article is distributed under the terms of the Creative Commons Attribution 4.0 International License (http://creativecommons.org/licenses/by/4 $.0 /$ ), which permits unrestricted use, distribution, and reproduction in any medium, provided you give appropriate credit to the original author(s) and the source, provide a link to the Creative Commons license, and indicate if changes were made.

\section{REFERENCES}

Allen JRL. 1990. Salt-marsh growth and stratification: a numerical model with special reference to the Severn Estuary, southwest Britain. Marine Geology 95:77-96.

Allen JRL. 2000. Morphodynamics of Holocene saltmarshes: a review sketch from the Atlantic and Southern North Sea coasts of Europe. Quaternary Science Reviews 19:1155-231.

Anthony EJ, Gratiot N. 2012. Coastal engineering and largescale mangrove destruction in Guyana, South America: Averting an environmental catastrophe in the making. Ecological Engineering 47:268-73.

Baer JU, Kent TF, Anderson SH. 2009. Image analysis and fractal geometry to characterise soil desiccation cracks. Geoderma 154:153-63.

Baker R, Sheaves M, Johnston R. 2015. Geographic variation in mangrove flooding and accessibility for fishes and nektonic crustaceans. Hydrobiologia 762:1-14.

Balke T, Swales A, Lovelock CE, Herman PMJ, Bouma TJ. 2015. Limits to seaward expansion of mangroves: Translating physical disturbance mechanisms into seedling survival gradients. Journal of Experimental Marine Biology and Ecology 467:16-25.
Bell RG, Goring DG, de Lange WP. 2000. Sea-level change and storm surges in the context of climate change. IPENZ Transactions 27(1):1-10.

Bird ECF. 1986. Mangroves and intertidal morphology in Westernport Bay, Victoria, Australia. Marine Geology 69:25171.

Boumans R, Day JW. 1993. High precision measurements of sediment elevation in shallow coastal areas using a sedimentation-erosion table. Estuaries 16:375-80.

Cahoon DR, Turner RE. 1989. Accretion and canal impacts in a rapidly subsiding wetland II. Feldspar marker horizon technique. Estuaries 12:260-8.

Cahoon DR, Reed DR, Day JW. 1995. Estimating shallow subsidence in microtidal salt marshes of the southeastern United States: Kaye and Barghoorn revisited. Marine Geology 128:19.

Cahoon DR, Reed DJ. 1995. Relationships among marsh surface topography, hydroperiod and soil accretion in a deteriorating Louisiana Salt Marsh. Journal of Coastal Research 11(2):35769.

Cahoon DR, Lynch JC. 1997. Vertical accretion and shallow subsidence in a mangrove forest of southwestern Florida, USA. Mangroves and Salt Marshes 1:173-86.

Cahoon DR, Day JW, Reed DJ. 1999. The influence of surface and shallow subsurface soil processes on wetland elevation: a synthesis. Current Topics in Wetland Biogeochemistry 3:7288.

Cahoon DR, Lynch JC, Perez BC, Segura B, Holland RD, Stelley C, Stephenson G, Hensel P. 2002. High-precision measurements of wetland elevation: II. The Rod Surface Elevation Table. Journal of Sedimentary Research 72(5):734-9.

Cahoon DR, Hensel P, Rybczyk J, McKee KL, Proffitt CE, Perez BA. 2003. Mass tree mortality leads to mangrove peat collapse at Bay Islands, Honduras after Hurricane Mitch. Journal of Ecology 91:1093-105.

Cahoon DR, Hensel PF, Spencer T, Reed DJ, McKee KL, Saintilan N. 2006. Coastal wetland vulnerability to relative sea-level rise: wetland elevation trends and process controls. In: Verhoeven JTA et al., Eds. Wetlands and Natural Resource Management. Berlin: Springer-Verlag. p 271-92.

Cahoon DR, Reed DJ, Kolker A, Brinson MM, Stevenson JC, Riggs S, Christian R, Reyes E, Voss C, Kunz D. 2009. Coastal wetland sustainability. In: Titus JG, Anderson KE, Cahoon DR, Gill S, Thieler ER, Williams SJ (Lead authors). Coastal Sensitivity to Sea-Level Rise: A Focus on the Mid-Atlantic Region. A report by the U.S. Climate Change Science Program and the Subcommittee on Global Change Research. U.S. Environmental Protection Agency, Washington D.C., USA, pp $57-72$.

Cahoon DR, Guntenspergen GR. 2010. Climate change, sea-level rise and coastal wetlands. National Wetlands Newsletter JanFeb 2010, 8-12.

Cahoon DR, Perez BC, Segura BD, Lynch JC. 2011. Elevation trends and shrink-swell response of wetland soils to flooding and drying. Estuarine, Coastal and Shelf Science 91:463-74.

Cahoon DR. 2015. Estimating relative sea-level rise and submergence potential at a coastal wetland. Estuaries and Coasts 38(3):1077-84. https://doi.org/10.1007/s12237-104-9872-8.

Christie MC, Dyer KR, Turner P. 1999. Sediment flux and bed level measurements from a macro tidal mudflat. Estuarine, Coastal and Shelf Science 49:667-88. 
Clarke PJ, Myerscough PJ. 1993. The intertidal distribution of the grey mangrove (Avicennia marina) in southeastern Australia: The effects of physical conditions, interspecific competition, and predation on propagule establishment and survival. Australian Journal of Ecology 18:307-15.

Coelho H, Vieira S, Serôdio J. 2009. Effects of desiccation on the photosynthetic activity of intertidal microphytobenthos biofilms as studied by optical methods. Journal of Experimental Marine Biology and Ecology 381:98-104.

De'ath G. 2007. Boosted trees for ecological modelling and prediction. Ecology 88:243-51.

De Vries H, Breton M, de Mulder T, Krestennitis Y, Ozer J, Proctor R, Ruddick K, Salomon J, Voorrips A. 1995. A comparison of 2D storm surge models applied to three shallow European seas. Environmental Software 10(1):23-42.

Egler F. 1952. Southeast saline Everglades vegetation, Florida, and its management. Vegetatio 3:213-65.

Elith J, Leathwick JR, Hastie T. 2008. A working guide to boosted regression trees. Journal of Animal Ecology 77:802-13.

Fagherazzi S, Kirwan ML, Mudd SM, Guntenspergen GR, Temmerman S, D'Alpaos A, van de Koppel J, Rybczyk J, Reyes E, Craft C, Clough J. 2012. Numerical Models of Salt Marsh Evolution: Ecological, Geomorphic, and Climatic Factors. Environmental Sciences Faculty Publications 10. http s://cedar.wwu.edu/esci_facpubs/ 10 .

Feller IC, Lovelock CE, Berger U, McKee KL, Joye SB, Ball MC. 2010. Biocomplexity in mangrove ecosystems. Annual Reviews 2:395-417.

French J. 2006. Tidal marsh sedimentation and resilience to environmental change: Exploratory modelling of tidal, sealevel and sediment supply forcing in predominantly allochthonous systems. Marine Geology 235:119-36.

Friedman JH. 2001. Greedy function approximation: a gradient boosting machine. Annals of Statistics 29:1189-232.

Friess DA, Krauss KW, Horstman EM, Balke T, Bouma TJ, Galli D, Webb EL. 2012. Are all intertidal wetlands naturally created equal? Bottlenecks, thresholds and knowledge gaps to mangrove and saltmarsh ecosystems. 2012. Biological Reviews 87:346-66.

Furukawa K, Wolanski E, Mueller H. 1997. Currents and sediment transport in mangrove forests. Estuarine, Coastal and Shelf Science 44:301-10.

Gattuso JP et al. 2015. Contrasting futures for ocean and society from different anthropogenic $\mathrm{CO}_{2}$ emission scenarios. Science 349(6243):45. https://doi.org/10.1126/science.aac4722.

Gibbs MM, Swales A, Olsen G. 2014. Suess Effect on biomarkers used to determine sediment provenance from land use changes. In Proceedings - International Symposium on Managing Soils for food Security and Climate Change Adaption and Mitigation, Heng LK, Sakadevan K, Dercon G, Nguyen ML. (eds). Food and Agriculture Organization of the United Nations Rome, 2014: 371-375.

Gladstone-Gallagher R, Lundquist CJ, Piltditch CA. 2014. Mangrove (Avicennia marina subsp. Australasica) litter production and decomposition in a temperate estuary. New Zealand Journal of Marine and Freshwater Research 48(1):24-37.

Gong W, Shen J, Reay WG. 2007. The hydrodynamic response of the York River estuary to Tropical Cyclone Isabel. Coastal, Estuarine and Shelf Science 73:695-710.

Goring DG. 1995. Short-term variations in sea level (2-15 days) in the New Zealand region. New Zealand Journal of Marine and Freshwater Research 29:69-82.
Goring DG, Bell RG. 1999. El Nino and decadal effects on sealevel variability in northern New Zealand: a wavelet analysis. New Zealand Journal of Marine and Freshwater Research 33:587-98.

Goring DG, Stephens SA, Bell RG, Pearson CP. 2011. Estimation of extreme sea levels in a tide-dominated. Environment using short data records. Journal of Waterway, Port, Coastal and Ocean Engineering May/June 2011:150-9.

Gray JR, Simões JM. 2008. Appendix D - Estimating Sediment Discharge. In: Garcia M, Ed. Sedimentation Engineering: Processes. Measurements, Modeling and Practice: American Society of Civil Engineers. p 1065-86.

Green MO. 2011. Very small waves and associated sediment resuspension on an estuarine intertidal flat. Estuarine, Coastal and Shelf Science 93:449-59.

Green MO, Black KP, Amos CL. 1997. Control of estuarine sediment dynamics by interactions between currents and waves at several scales. Marine Geology 144:97-116.

Green MO, Coco G. 2007. Sediment transport on an estuarine intertidal flat: measurements and conceptual model of waves, rainfall and exchanges with a tidal creek. Estuarine Coastal and Shelf Science 72:553-69.

Green MO, Coco G. 2014. Review of wave-driven sediment resuspension and transport in estuaries. Reviews of Geophysics 52:77-117.

Hicks DM, Shankar U, McKerchar AI, Basher L, Jessen M, Lynn I, Page M. 2011. Suspended sediment yields from New Zealand rivers. Journal of Hydrology (NZ) 50(1):81-142.

Hicks DM, Gomez B. 2016. Sediment Transport. In: Kondolf GM, Piégay H, Eds. Tools in Fluvial Geomorphology. Second Edition: John Wiley and Sons. p 324-56.

Hume TM, McGlone MS. 1986. Sedimentation patterns and catchment use changes recorded in the sediments of a shallow tidal creek, Lucas Creek, Upper Waitemata Harbour, New Zealand. Journal of the Royal Society of New Zealand 19:30517.

Kamphuis JW. 2002. Introduction to Coastal engineering and Managment. Advaanced Series on Ocean Engineering - Volume 16. World Scientific Publishing, Singapore, 437 p.

Kaye CA, Barghoorn ES. 1964. Late Quaternary sea-level change and crustal rise at Boston Massachusetts, with notes on the autocompaction of peat. Geological Society of America Bulletin 75:63-80.

Krauss K, Allen JA, Cahoon DR. 2003. Differential rates of vertical accretion and elevation change among aerial root types in Micronesian mangrove forests. Estuarine, Coastal and Shelf Science 56:251-9.

Krauss KW, Doyle TW, Twilley RR, Rivera-Monroy VH, Sullivan JK. 2006. Evaluating the relative contributions of hydroperiod and soil fertility on growth of south Florida mangroves. Hydrobiologia 569:31 1-24.

Krauss KW, Lovelock CE, McKee KL, Lopez-Hoffman L, Ewe SML, Sousa WP. 2008. Environmental drivers in mangrove establishment and early development: a review. Aquatic Botany 89:105-27.

Krauss KW, Cahoon DR, Allen JA, Ewel KC, Lynch JC, Cormier NC. 2010. Surface elevation change and susceptibility of different mangrove zones to sea-level rise on Pacific high islands of Micronesia. Ecosystems 13:129-43.

Krauss KW, McKee KL, Lovelock CE, Cahoon DR, Saintilan N, Reef R, Chen L. 2014. How mangroves adjust to rising sea level. New Phytologist, https://doi.org/10.1111/nph.12605. 
Kumara MP, Jayatissa LP, Krauss KW, Phillips DH, Huxham M. 2010. High mangrove density enhances surface accretion, surface elevation change, and tree survival in coastal areas susceptible to sea-level rise. Oecologia 164:545-53.

Leathwick JR, Elith J, Chadderton WL, Rowe D, Hastie T. 2008. Dispersal, disturbance and the contrasting biogeographies of New Zealand's diadromous and non-diadromous fish species. Journal of Biogeography 35:1481-97.

Leonardi N, Ganju NK, Fagherazzi S. 2016. A linear relationship between wave power and erosion determines salt-marsh resilience to violent storms and hurricanes. Proceeding of the National Academy of Sciences 113:64-8.

Li M, Zhong L, Boicourt WC, Zhang S, Zhang D-L. 2006. Hurricane-induced storm surges, currents and destratification in a semi-enclosed bay. Geophysical Research Letters 33:L02604. h ttps://doi.org/10.1029/2005GL024992.

Lovelock CE, Sorrell BK, Hancock N, Hua Q, Swales A. 2010. Mangrove forest and soil development on a rapidly accreting shore in New Zealand. Ecosystems 13:437-51.

Lovelock CE, Bennion V, Grinham A, Cahoon DR. 2011. The role of surface and subsurface processes in keeping pace with sea level rise in intertidal wetlands of Moreton Bay, Queensland, Australia. Ecosystems 14(5):745-57.

Lovelock CE, Adame MF, Bennion V, Hayes M, Reef R, Santini N, Cahoon DR. 2015a. Sea level and turbidity controls on mangrove surface elevation change. Estuarine, Coastal and Shelf Science 153:1-9.

Lovelock CE, Cahoon DR, Friess DA, Guntenspergen GR, Krauss KW, Reef R, Rogers K, Saunders M, Sidik F, Swales A, Saintilan N, Thuyen LX, Triet T. 2015b. The vulnerability of IndoPacific mangrove forests to sea level rise. Nature 526:559-63. https://doi.org/10.1038/nature15538.

Lugo AE, Snedaker SC. 1974. The ecology of mangroves. Annual Review of Ecology and Systematics 5:39-64.

Lund ZF, Pearson RW, Buchanan GA. 1970. An implanted soil mass technique to study herbicide effects on root growth. Weed Science 18:279-81

Marani M, D’Alpaos A, Lanzoni S, Carniello L, Rinaldo A. 2010. The importance of being coupled: Stable states and catastrophic shifts in tidal biomorphodynamics. Journal of Geophysical Research 115:F04004. https://doi.org/10.1029/2009JF001600.

Mariotti G, Fagherazzi S. 2013. Wind waves on a mudflat: The influence of fetch and depth on bed shear stresses. Continental Shelf Research 60S:S99-110.

Martínez-Rincóna RO, Ortega-Garcíab S, Vaca-Rodríguez JG. 2012. Comparative performance of generalized additive models and boosted regression trees for statistical modeling of incidental catch of wahoo (Acanthocybium solandri) in the Mexican tuna purse-seine fishery. Ecological Modelling 233:20-5.

MATLAB ${ }^{\circledR}$. High-Performance Numeric Computation and Visualization Software. The Math Works Inc., Natick, MA, United States of America.

Mazda Y, Wolanski E. 2009. Hydrodynamics and modelling of water flow in mangrove areas. In: Perillo GME et al., Eds. Coastal Wetlands-An Integrated Ecosystem Approach. Amsterdam: Elsevier. p 231-61.

McAnally WH, Friedrichs C, Hamilton D, Hayter E, Shresthar P, Rodriguez H, Sheremet A, Teeter A. 2007. Management of fluid mud in estuaries, bays, and lakes. 1. Present state of understanding on character and behaviour. Journal of Hydraulic Engineering 133(1):9-22.
McKee KL, Cahoon DR, Feller IC. 2007. Caribbean mangroves adjust to rising sea level through biotic controls on change in soil elevation. Global Ecology and Biogeography 16:545-56.

McKee KL. 2011. Biophysical controls on accretion and elevation change in Caribbean mangrove ecosystems. Estuarine, Coastal and Shelf Science 91:475-83.

Mitchell JK. 1993. Fundamentals of soil behaviour. New York: Wiley.

Morrisey DJ, Swales A, Dittmann S, Morrison MA, Lovelock CE, Beard CM. 2010. The Ecology and Management of Temperate Mangroves. Oceanography and Marine Ecology: An Annual Review 48:43-160.

Munson BR, Young DF, Okiishi TH. 1998. Fundamentals of Fluid Mechanics. Third Edition. John Wiley and Sons, $877 \mathrm{pp}$.

Naish TR, Nelson CS, Hodder PW. 1993. Evolution of Holocene sedimentary bentonite in a shallow marine embayment, Firth of Thames, New Zealand. Marine Geology 109:267-78.

Oldman JW, Black KP, Swales A, Stroud MJ. 2009. Prediction of annual average sedimentation rates in an estuary using numerical models with verification against core data Mahurangi Estuary, New Zealand. Estuarine, Coastal and Shelf Science 84:483-92.

Pawlowicz R, Beardsley B, Lentz S. 2002. Classical tidal harmonic analysis including error estimates in MATLAB using T_TIDE. Computers and Geosciences 28:929-37.

Pinheiro J, Bates D, DebRoy S, Sarkar, D, and R-Core Team. 2016. nlme: Linear and Nonlinear Mixed Effects Models. R package version 3.1-128.

Plummer PS, Gostin VA. 1981. Shrinkage cracks: desiccation or synaeresis? Journal of Sedimentary Petrology 51(4):1147-56.

Postma H. 1961. Transport and accumulation of suspended matter in the Dutch Wadden Sea. Netherlands Journal of Sea Research 1:148-90.

Pugh DT. 1987. Tides, Surges and Mean Sea Level. Chichester, United Kingdom: John Wiley and Sons. p 472.

Reed DJ. 1990. The impact of sea-level rise on coastal saltmarshes. Progress in Physical Geography 14(4):465-81.

Reineck HE, Singh IB. 1980. Depositional Sedimentary Environments, second. second revised edn. Berlin: Springer-Verlag.

Ridgeway G. 2006. Generalized boosted regression models Documentation on the R Package 'gbm', version 1.5-7. http:// www.i-pensieri.com/gregr/gbm.shtml, accessed March 2008.

Rogers K, Saintilan N, Heijnis H. 2005a. Surface elevation dynamics in a regenerating mangrove forest at Homebush Bay, Australia. Wetlands Ecology and Management 13:58798.

Rogers K, Saintilan N, Heijnis H. 2005b. Mangrove encroachment of salt marsh in Western Port Bay, Victoria: the role of sedimentation, subsidence and sea level rise. Estuaries 28:551-9.

Rogers K, Wilton KM, Saintilan N. 2006. Vegetation change and surface elevation dynamics in estuarine wetlands of southeast Australian. Estuarine, Coastal and Shelf Science 66:559-69.

Rogers K, Saintilan N. 2008. Relationships between surface elevation and groundwater in mangrove forests of southeast Australia. Journal of Coastal Research 24A:63-9.

Rogers K, Saintilan N, Howe AJ, Rodríguez JF. 2013. Sedimentation, elevation and marsh evolution in a southeastern Australian estuary during changing climatic conditions. Estuarine, Coastal and Shelf Science 133:172-81. 
Rogers K, Saintilan N, Woodroffe CD. 2014. Surface elevation change and vegetation distribution dynamics in a subtropical coastal wetland: implications for coastal wetland response to climate change. Estuarine, Coastal and Shelf Science 149:4956.

Sheffield AT, Healy TR, McGlone MS. 1995. Infilling rates of a steepland catchment estuary, Whangamata, New Zealand. Journal of Coastal Research 11(4):1294-308.

Sidik F, Neil D, Lovelock CE. 2016. Effect of high sedimentation rates on surface sediment dynamics and mangrove growth in the Porong River, Indonesia. Marine Pollution Bulletin 107(1):355-63.

Steel ZL, Steel AE, Williams JN, Viersc JH, Marquet PA, Barbosa O. 2017. Patterns of bird diversity and habitat use in mixed vineyard-matorral landscapes of Central Chile. Ecological Indicators 73:345-57.

Stephens SA, Bell RG, Ramsay D, Goodhue N. 2014. High-water alerts from coinciding astronomical tide and high mean sea level anomaly in the Pacific Islands Region. Journal of Atmospheric and Oceanic Technology 31:2829-43.

Stephens SA, Robinson B, Bell RG. 2015. Analysis of Whitianga, Tararu and Kawhia sea-level records to 2014. NIWA Client Report HAM2015-046 for Waikato Regional Council, 98 p.

Stokes DJ, Healy T, Cooke PJ. 2009. Surface elevation changes and sediment characteristics of intertidal surfaces undergoing mangrove expansion and mangrove removal, Waikaraka Estuary, Tauranga Harbour, New Zealand. International Journal of Ecology and Development 12:88-106.

Swales A, Williamson RB, Van Dam LF, Stroud MJ, McGlone MS. 2002. Reconstruction of urban stormwater contamination of an estuary using catchment history and sediment profile dating. Estuaries 25:43-56.

Swales A, MacDonald IT, Green MO. 2004. Influence of wave and sediment dynamics on cord grass (Spartina anglica) growth and sediment accumulation on a wave-exposed intertidal flat. Estuaries 27(2):225-43.

Swales A, Bentley SJ, Lovelock C, Bell RG. 2007. Sediment processes and mangrove-habitat expansion on a rapidly-prograding muddy coast, New Zealand. In: Kraus, N.C. and Rosati, J.D. (eds.) Coastal Sediments'07 (volume 2): 1441-1454. Proceedings of the Sixth International Symposium on Coastal Engineering and Science of Coastal Sediment Processes, New Orleans, 13-17 May 2007. American Society of Civil Engineers, Reston Virginia, USA.

Swales A, Bentley SJ, Lovelock CE. 2015. Mangrove-forest evolution in a sediment-rich estuarine system: Opportunists or agents of geomorphic change? Earth Surface Processes and Landforms 40:1672-87.

Swales A, Denys P, Pickett VI, Lovelock CE. 2016. Evaluating deep subsidence in a rapidly accreting mangrove forest using GPS monitoring of surface-elevation benchmarks and sedimentary records. Marine Geology 380:205-18.

Talke SA, Stacey MT. 2008. Suspended sediment fluxes at an intertidal flat: The shifting influence of wave, wind, tidal and freshwater forcing. Continental Shelf Research 28:710-25.

van Maren DS, Winterwerp JC. 2013. The role of flow asymmetry and mud properties on tidal flat sedimentation. Continental Shelf Research 60S:S71-84.

Venables WN, Ripley BD. 2002. Modern Applied Statistics with S. New York: Springer, 4th Edition.

Webb EL, Friess DA, Krauss KW, Cahoon DR, Guntenspergen GR, Phelps J. 2013. A global standard for monitoring coastal wetland vulnerability to accelerated sea-level rise. Nature Climate Change 3:458-65.

Whelan KRT, Smith TJ, Cahoon DR, Lynch JC, Anderson GH. 2005. Groundwater control of mangrove surface elevation: Shrink and swell varies with soil depth. Estuaries 28:833-43.

Whunch C, Stammers D. 1997. Atmospheric loading and the oceanic "inverted barometer" effect. Reviews of Geophysics 35(1):79-107.

Williams J, Horsburgh KJ, Williams JA, Proctor RNF. 2016. Tide and skew surge independence: New insights for flood risk. Geophysical Research Letters 43:6410-17.

Woodroffe CD. 1985. Studies of a mangrove basin, Tuff Crater, New Zealand: I. Mangrove biomass and production of detritus. Estuarine, Coastal and Shelf Science 20:265-80.

Woodroffe CD. 1992. Mangrove sediments and geomorphology. In: Robertson AI, Alongi DM, Eds. Tropical mangrove ecosystems. Washington DC: American Geophysical Union. p 7-41.

Woodroffe CD, Rogers K, McKee KL, Lovelock CE, Mendelssohn IA, Saintilan N. 2016. Mangrove sedimentation and response to relative sea level rise. Annual Reviews in Marine Science 8:243-66.

Yesiller N, Miller CJ, Inci G, Yaldo K. 2000. Desiccation and cracking behaviour of three compacted landfill liner soils. Engineering Geology 57:105-21.

Young BM, Harvey LE. 1996. A spatial analysis of the relationship between mangrove (Avicennia marina var. australasica) physiognomy and sediment accretion in the Hauraki Plains, New Zealand. Estuarine Coastal and Shelf Science 42:231-46. 